\title{
TOWARD A NEW SOCIAL-POLITICAL THEORY OF THE PUBLIC TRUST DOCTRINE
}

\section{Haochen Sun*}

The sovereign power itself. . cannot, consistently with the principles of the law of nature and the constitution of a well ordered society, make a direct and absolute grant of the waters of the state, divesting all the citizens of their common right. It would be a grievance which never could be long borne by a free people. ${ }^{1}$

-Justice Kirkpatrick

[T]his taking upon ourselves the consequences for things we are entirely innocent of, is the price we pay for the fact that we live our lives not by ourselves but ... [within a] human community. ${ }^{2}$

-Hannah Arendt

\begin{abstract}
This Article puts forward a new social-political theory of the public trust doctrine by demonstrating that the doctrine is a legal tool that embodies both rights-conferring and responsibilities-imposing functions. The new theory, as the Article shows, is capable of yielding effective responses to the criticisms that have been leveled against the doctrine and the conventional theories upon which the doctrine was founded.

Based on the role of public space in human development, the Article first discusses how and why the public trust doctrine has functioned to protect public spaces by conferring upon citizens four categories of public rights. The Article then argues that we should regard the public trust doctrine as a legal tool to enforce the public trust principle as a fundamental constitutional principle affording citizens fundamental rights over public space that is indispensable for human development. The protection of the public interest under this principle embodies the fundamental human value of protecting public space and underscores the need for the legal system to be shaped in a manner that effectuates this human value.
\end{abstract}

* Haochen Sun, Assistant Professor of Law and Deputy Director of the Law and Technology Center, University of Hong Kong. I am grateful to James Boyle, Albert Chen, William Fisher, Gerald Frug, Jedediah Purdy, Joseph Singer, Laura Underkuffler, Stephanie Wang, and Peter Yu for their help, support, or comments. I also want to thank participants at the 9th Annual Intellectual Property Scholars Conference, the 2009 Intellectual Property Scholars Roundtable, and the Visiting Scholars \& Researchers Colloquium at Harvard Law School for their helpful comments on an earlier draft.

1. Arnold v. Mundy, 6 N.J.L. 1, 78 (N.J. 1821).

2. HannAh ARENDT, ReSPONSIBILITY AND Judgment 157-58 (Jerome Kohn ed., 2003). 
Moreover, the Article contends that while it grants citizens fundamental rights over public spaces, the public trust principle underlying the public trust doctrine also impresses social responsibilities upon the stakeholders regarding the protection of public space. Through the enforcement of social responsibilities, the doctrine promotes a stewardship ethic of protecting the public spaces in society. In this respect, the Article alters the conventional trusteeship model under the public trust doctrine, which deems the government to be the sole trustee responsible for managing public resources. It demonstrates that the social responsibility model of stewardship requires not only the government but also the judiciary and individuals as members of the public to act as the stewards of public resources.

\section{TABLE OF CONTENTS}



I. The UneAsy CASE FoR THE Public TRUST DoctRINE .........................570

A. The Historical Trajectory of the Public Trust Doctrine .................570

B. The Great Debate About the Public Trust Doctrine ........................576

II. The Public TRust Principle of PROTECTING

THE FundAMENTAL RightS OVER PUBLIC SPACE ...............................581

A. The Role of Private and Public Space in Human Development.. .581

B. The Asymmetry of Legal Protections of Private Spaces and Public Spaces..... 585

C. Public Trust Doctrine as a Legal Tool to Defend Public Space....

D. The Public Trust Doctrine as a Legal

Tool to Enforce the Public Trust Principle.

III. ENFORCING SOCIAL RESPONSIBILITIES

BY PROMOTING THE STEWARDSHIP ETHIC

A. Defending the Public's Collective Interest ..............................600

B. Social Responsibilities and the Stewardship Ethic..................603

IV. RESPONDING TO CRITICISMS OF THE PUBLIC TRUST DOCTRINE...........613

A. Concern About Judicial Incompetence ...................................614

B. Concern About the Danger of Judicial Supremacy .................617

C. Concern About the Tragedy of the Commons ..........................619

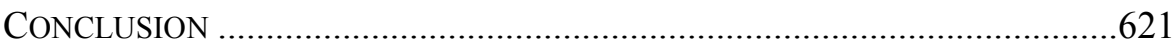




\section{INTRODUCTION}

Our public spaces are very vulnerable to a variety of degradations. The harm caused by degradations can be widespread and even irreparable. The recent Gulf of Mexico oil spill clearly demonstrated that an unexpected degradation to public space can even bring about an environmental disaster unprecedented in American history. Its consequences are so grave and widespread that many see it as a national catastrophe that not only hits hard the ecology of the American southeast coast, but also constitutes a crisis of humanity caused by human greed. ${ }^{3}$

Compared with the oil spill that has drawn attention at a national and global level, many silent degradations of public space at a local level may cause serious consequences to people in the locality. Recently, many people in Pennsylvania towns engaged in battles against the disappearance of public parks in their neighborhoods. Private developers had attempted to force the closure of these public parks and their transfer to private control. ${ }^{4}$ The privatization of these public parks may only affect people who live in neighboring communities. But these parks are vital to community life because they provide free and open venues in which residents can socialize with one another or simply relax. Thus, public parks are crucial to community cohesion and social bonding. They are also closely intertwined with individual well-being, simply because life is better with green areas and recreational facilities open to the public.

These degradations of public spaces at the national or local level raise the question of how to prevent or stop them both in the short and long run. The public trust doctrine has been invoked to address these problems. ${ }^{5}$ At least in the case of the public park, the public trust doctrine helped the local

3. Donna Brazile, Greed, negligence behind BP oil spill, CNN.COM, May 3, 2010, http://edition.cnn.com/2010/OPINION/05/03/brazile.oil.new.orleans/index.html ("The BP disaster has only one cause: human greed, and the almost inevitable result, negligence.").

4. See, e.g., Background, SAVE KARDON PARK, http://savekardonpark.com/3.html (last visited Jan. 20, 2011) (explaining citizens' efforts to prevent developers from building a large housing and commercial development in Kardon Park); Burholme Park, Public VOICE FOR Public SPaCE, http://www. publicvoiceforpublicspace.org/index.php?option=com_content\&view=category\&id=7:burholmepark\&layout=blog\&Itemid=18 (last visited Jan. 20, 2011) (discussing community members' success at blocking the development of Burholme Park); Save Burholme Park, SAVE BuRHOLME PARK, http://saveburholmepark.org (last visited Jan. 20, 2011) (noting the importance of Burholme Park to the surrounding community).

5. See, e.g., Mary Turnipseed et al., Legal Bedrock for Rebuilding America's Ocean Ecosystems, 324 SCI. 183, 183-84 (2009); Rafe Sagarin \& Mary Turnipseed, The Gulf oil Disaster and the Public Trust Doctrine, MCClatchY NEwSPAPERS, June 11, 2010, available at http://www.mcclatchydc.com/2010 /06/11/95601/commentary-the-gulf-oil-disaster.html. 
residents to preserve the park. ${ }^{6}$ Historically, the public trust doctrine has played an important role in deterring inappropriate exploitation of public resources by governmental bodies and private parties. By legalizing the public property status of certain resources that are critical for the common good of society, ${ }^{7}$ the doctrine prohibits both state and private actions that would harm public interests in these resources.

Joseph Sax, the pioneering figure in the public trust doctrine movement, once boldly stated that "[o]f all the concepts known to American law, only the public trust doctrine seems to have the breadth and substantive content which might make it useful as a tool of general application for citizens seeking to develop a comprehensive legal approach to resource management problems." Indeed, the public trust doctrine played an important part in kindling the environmental movement in the early 1970s. ${ }^{9}$ The past few decades also witnessed an increasingly broad expansion of the doctrine by courts. Originally focused on protecting resources for navigation, commerce, and fishing, the public trust doctrine has evolved into a legal tool for ecological preservation and recreational use of certain public resources. ${ }^{10}$

In academia, there has been a mushrooming of proposals to address critical social problems in allocating and managing human resources, ranging from cultural heritage, ${ }^{11}$ to the radio spectrum, ${ }^{12}$ to intellectual property. ${ }^{1}$

6. Applying the public trust doctrine, the Commonwealth Court in Pennsylvania rejected the City of Philadelphia's decision to lease the Burholme Park to the Fox Chase Cancer Center. See Press Release, SCRUB, Victory in the Courts: Public Trust Doctrine Prevents Lease of Parkland (Dec. 9, 2008), available at http://www.defenseofplace.org/burholme.pdf. The court's ruling was largely based on the public trust doctrine. Id.

7. Carol M. Rose, Joseph Sax and the Idea of the Public Trust, 25 ECOLOGY L.Q. 351, 351 (1998) (pointing out that the public trust doctrine promotes the human values of "guardianship, responsibility, and community"); Charles F. Wilkinson, The Public Trust Doctrine in Public Land Law, 14 U.C. DAVIS L. REV. 269, 315 (1980) ("The public trust doctrine is rooted in the precept that some resources are so central to the well-being of the community that they must be protected by distinctive, judge-made principles.").

8. Joseph L. Sax, The Public Trust Doctrine in Natural Resource Law: Effective Judicial Intervention, 68 MicH. L. REV. 471, 474 (1970).

9. See, e.g., Douglas A. Kysar, The Consultants' Republic, 121 HARV. L. Rev. 2041, 2059-60 (2008) (book review) (discussing the role of the public trust doctrine in environmental movement); Erin Ryan, Public Trust and Distrust: Theoretical Implications of the Public Trust Doctrine for Natural Resource Management, 31 ENVTL. L. 477, 479-80 (2001) ("Environmental activists widely hailed the emergence of the new public trust as the legal tool that would finally empower them against powerful private and government interests they believed imperiled natural resources nationwide.").

10. AleXandra B. Klass \& Ling-Yee Huang, Ctr. For Progressive Reform, Restoring the Trust: Water Resources and the Public Trust Doctrine, A Manual for Advocates, White PaPer No. 908, at 4-5 (2009), http://www.progressivereform.org/articles/CPR_Public_Trust_Doctrine_Manual.pdf ("From its historical roots in navigation, fishing, and commerce, the doctrine has evolved to encompass modern public uses that include recreation and aesthetic uses and environmental preservation.”).

11. See, e.g., Kristen A. Carpenter, A Property Rights Approach to Sacred Sites Cases: Asserting a Place for Indians as Nonowners, 52 UCLA L. REV. 1061, 1119-20 (2005) (proposing that 
Recently, the Colorado state legislature considered whether their state constitution should be amended to include the public trust doctrine. ${ }^{14}$ At the global level, there are calls for a blue covenant among nations to redefine the world's fresh water as a public trust resource rather than a commercial product. $^{15}$

While the public trust doctrine has played an increasingly important role in protecting natural resources and the public interest, it has also attracted scathing criticisms of the theoretical foundation of the doctrine and its concomitant expansive scope of application. Criticisms have been leveled against its counter-majoritarian ${ }^{16}$ pedigree in our democratic system, ${ }^{17}$ its lack

"the public trust doctrine may support the right of citizens (including American Indian citizens) to use public lands for religious and cultural purposes, and it explores the accompanying federal duty to facilitate such uses"); Nicole B. Wilkes, Public Responsibilities of Private Owners of Cultural Property: Toward a National Art Preservation Statute, 24 COLUM.-VLA J.L. \& ARTS 177, 195 (2001) (arguing that "[t]he public trust doctrine ... could be extended to safeguard art objects that are subjected to extensive public use"). Similar public interest-based models could be found in the other two works. See Kristen Carpenter et al., In Defense of Property, 118 YALE L.J. 1022, 1029 (2009) (employing a public interestbased model to sites of cultural significance); see also JoSEPH L. SAX, PLAYING DARTS WITH A REMBRANDT: PUBlic AND PRivate Rights In Cultural Treasures (1999).

12. See, e.g., Patrick S. Ryan, Application of the Public-Trust Doctrine and Principles of Natural Resource Management to Electromagnetic Spectrum, 10 Мich. Telecomm. \& TeCH. L. ReV. 285, 287 (2004) (arguing that the public trust doctrine should be applied to the electromagnetic spectra to promote fair and efficient use).

13. See Maureen Ryan, Cyberspace as Public Space: A Public Trust Paradigm for Copyright in a Digital World, 79 OR. L. REV. 647, 647 (2000).

14. See initiative fOR Adoption of the Colorado Public Trust Doctrine, http://www.leg.state.co.us/LCS/Initiative\%20Referendum/1112InitRefr.nsf/dac421 ef79ad243487256def006 7c1de/d342a9d87efbc57c87257719004fc379/\$FILE/2011-2012\%20\%233.pdf (last visited Jan. 29, 2011).

15. See Maude Barlow, Blue Covenant: The Global Water Crisis and the Coming BATTLE FOR THE RIGHT TO WATER (2008) (arguing that the world's fresh water supply should be held in the public trust); Ved P. Nanda \& William K. Ris, Jr., The Public Trust Doctrine: A Viable Approach to International Environmental Protection, 5 ECOLOGY L.Q. 291, 291-92 (1976) (advocating the establishment of an international public trust doctrine through an international convention).

16. The term was coined by Alexander Bickel. See AleXander M. Bickel, The Least Dangerous Branch: The Supreme Court at the Bar of Politics 16-23 (Josephine Ann Bickel, $2 d$ ed. 1986) (1962) (arguing that judicial review is illegitimate because it allows unelected judges to strike down the laws made by elected representatives and that judicial review by nature undermines the will of the majority of people).

17. Some critics argued that expansive use of the public trust doctrine would unreasonably interfere with private property rights and result in judicial supremacy. See James L. Huffman, A Fish Out of Water: The Public Trust in a Constitutional Democracy, 19 ENVTL. L. 527, 567 (1988) [hereinafter Huffman, A Fish Out of Water]; James L. Huffman, Speaking of Inconvenient Truths-A History of the Public Trust Doctrine, 18 DuKE EnVTL. L. \& POL'Y F. 1, 2 (2007) (explaining the misunderstood history behind the public trust doctrine); Geoffrey R. Scott, The Expanding Public Trust Doctrine: A Warning to Environmentalists and Policy Makers, 10 FORDHAM ENVTL. L.J. 1 (1998); George P. Smith II \& Michael W. Sweeney, The Public Trust Doctrine and Natural Law: Emanations Within a Penumbra, 33 B.C. ENVTL. AFF. L. REV. 307, 322-41 (2006). 
of flexibility in accommodating administrative expertise in managing natural resources, ${ }^{18}$ and its hostility toward private property protection. ${ }^{19}$

Despite the rapid development in application of the public trust doctrine, the conventional wisdom about the theoretical foundation of the doctrine, this Article shows, has failed to render a solid response to waves of criticisms leveled against it. ${ }^{20}$ Joseph Sax, the pioneering figure in the public trust doctrine movement, and his fellow advocates have clung to the view that the doctrine is tied to the necessity of using judicial supervision of the governmental management of resources held in trust for the public. To them, the doctrine essentially recognizes and enforces a common law right of the public to certain natural resources. These ideas are admirable. However, there are defects inherent in them. Their focus on the judicial role in protecting the public interest not only fails to respond to the criticisms, but also neglects a more dynamic understanding of the social-political foundation of the public trust doctrine.

Against this backdrop, this Article argues that it is high time for us to revisit the theoretical foundation of the public trust doctrine. Drawing on the lessons from centuries of invoking the public trust doctrine to address a host of social problems, this Article puts forward a new social-political theory of the doctrine based on the role of public space in forming the basic human condition. Moreover, it discusses how a new model of the doctrine can work to further our collective interest in maintaining and enhancing the vitality of the social environment for human development.

This Article points out that it is narrow-minded to shape the public trust doctrine as a legal tool centered on the judiciary and judge-made rules in protecting the public interest. It argues that under the new social-political theory I propose, the doctrine should rather be recognized as a legal tool to enforce the public trust principle, a principle that is fundamental to our legal system in general and the constitutional protection of rights in particular. The public trust principle, by nature, affords citizens with fundamental

18. See, e.g., Richard J. Lazarus, Changing Conceptions of Property and Sovereignty in Natural Resources: Questioning the Public Trust Doctrine, 71 IOWA L. REV. 631, 633 (1986) (arguing that continued judicial reliance on the public trust doctrine may stifle the evolution of modern environmental law and regulation).

19. Randy T. Simmons, Property and the Public Trust Doctrine, PERC Policy Series39 (Apr. 2007), www.perc.org/pdf/ps39.pdf (discussing the potential threat the public trust doctrine poses to private property rights); Stephanie Reckord, Limiting the Expansion of the Public Trust Doctrine in New Jersey: A Way to Protect and Preserve the Rights of Private Ownership, 36 Seton Hall L. Rev. 249, 272-74 (2005) (criticizing the New Jersey Supreme Court's expansion of public trust rights to the dry sand areas of beaches to accommodate recreational use by the public); Barton H. Thompson, Jr., Judicial Takings, 76 VA. L. REV. 1449, 1453 (1990) (arguing that judicial changes in the law impacting private property rights should not be immune from a takings analysis).

20. See infra text accompanying notes $62-67$. 
rights over the public space that is indispensable for human development. The protection of the public interest under this principle embodies the fundamental human value of protecting public space and underscores the need for the legal system to be shaped in a manner that effectuates this human value.

Furthermore, the new social-political theory of the public trust doctrine that I propose goes beyond the conventional wisdom on the public trust doctrine along other fronts as well. First, it redefines the nature of the public rights protected by the public trust doctrine and enforced largely by judicial decisions. This Article argues that they should be recognized as citizens' fundamental rights that deserve constitutional protection. Second, it contends the public trust doctrine carries more than rights-conferring functions; it also imposes social responsibilities on the government, courts, and individuals as members of the public for the purpose of protecting public space. Through the enforcement of social responsibilities, the doctrine promotes a stewardship ethic for protecting public space. Third, this Article alters the conventional trusteeship model under the public trust doctrine, which deems the government to be the sole trustee responsible for managing public resources. It demonstrates that the social responsibility model of stewardship requires not only the government, but also the judiciary, and even individuals as members of the public, to be the stewards of public resources.

This Article proceeds as follows. Part I explores the development of the public trust doctrine in American law and discusses the nature of the controversies about the doctrine. Part II puts forward a new social-political theory of the doctrine by examining the role of public space in human development. Based on the new theory, it further considers the doctrine's rights-conferring functions. Part III argues that the public trust doctrine also imposes social responsibilities on the government, the judiciary, and individuals as members of the public. In this sense, the doctrine is a legal tool that embodies both rights-conferring and responsibilities-imposing functions. Part IV considers how the proposals made in the earlier two Parts can respond to the criticisms that have been leveled against the public trust doctrine. 


\section{THE Uneasy CASE For THE Public TRUST DOCTRINE}

\section{A. The Historical Trajectory of the Public Trust Doctrine}

\section{Roots in the European Civil and Common Laws}

The public trust doctrine has a venerable history. It is widely accepted that the doctrine stemmed from Roman law concepts of public property, which prescribed that the air, rivers, sea, and seashore were not subject to private ownership by individuals. Rather, they were dedicated to the use by the public. For example, the Institutes of Justinian states:

By the law of nature these things are common to mankind - the air, running water, the sea, and consequently the shores of the sea. No one, therefore, is forbidden to approach the seashore, provided that he respects habitations, monuments, and buildings which are not, like the sea, subject only to the law of nations. ${ }^{21}$

With the rise of free trade in Europe, the idea of the public trust was invoked by those who opposed the kings' and the feudal lords' exclusive control of certain natural resources essential to the manufacture and trade of products in the marketplace. Thus, the Roman law idea of public trust gradually took root in many common law and civil law jurisdictions in Europe. In England, thanks to the Magna Carta, the public trust doctrine was included as part of English common law in order to restrict the Crown's proprietary control over certain natural resources. It was mandated that the Crown's title to resources such as waterways and the foreshore was subject to the people's "common right to use these public trust lands and their resources for certain traditional purposes necessary to individual survival and livelihood, including navigation, commerce and fishing.",22

21. J. INST.2.1.1 (J. Thomas trans. 1975).

22. Megan Higgins, Public Access to the Shore: Public Rights and Private Property, in AMERICA's Changing CoAsts 183, 184 (Diana M. Whitelaw \& Gerald R. Visgilio eds., 2005). See also Shively v. Bowlby, 152 U.S. 1, 11 (1894).

By the common law, both the title and the dominion of the sea, and of rivers and arms of the sea, where the tide ebbs and flows, and of all the lands below high water mark, within the jurisdiction of the Crown of England, are in the King. Such waters, and the lands which they cover, either at all times, or at least when the tide is in, are incapable of ordinary and private occupation, cultivation and improvement; and their natural and primary uses are public in their nature, for 
In thirteenth-century Spain, public rights in navigable waterways were recognized in Spanish law. ${ }^{23}$ By the eleventh century a French law had been decreed that provided that "the public highways and byways, running water and springs, meadows, pastures, forests, heaths and rocks ... are not to be held by lords[;] . . . nor are they to be maintained ... in any other way than that their people may always be able to use them." 24 The French Civil Code later "perpetuated the notion of common property with respect to navigable rivers and streams, beaches, ports and harbours. $" 25$

\section{Illinois Central Railroad v. Illinois and Its Progeny}

Since England, France, and Spain colonized many parts of North America, the colonial period saw the first migration of the public trust doctrine into American law. In the 1840s, the idea of "public trust" emerged in Martin v. Waddell, ${ }^{26}$ in which the Supreme Court ruled that "the shores, and rivers, and bays, and arms of the sea, and the land under them ... [were] held as a public trust for the benefit of the whole community, to be freely used by all for navigation and fishery."27

American law fully adopted the public trust doctrine after Illinois Central Railroad v. Illinois, ${ }^{28}$ a Supreme Court decision of 1892 that is recognized as the "lodestar" of the modern public trust doctrine. ${ }^{29}$ The case concerned a land grant from the Illinois state legislature to the Illinois Central Railroad Company, which covered the Chicago lakeshore with 1,000 acres of submerged lands. In its decision, the Supreme Court invalidated the initial grant of the lands based on the public trust doctrine. The Court ruled

\footnotetext{
highways of navigation and commerce, domestic and foreign, and for the purpose of fishing by all the King's subjects. Therefore the title, jus privatum, in such lands, as of waste and unoccupied lands, belongs to the King as the sovereign; and the dominion thereof, jus publicum, is vested in him as the representative of the nation

Id. and for the public benefit.

23. See Las Siete Partidas 821 (Robert I. Burns ed., Samuel Parsons Scott trans., University of Pennsylvania Press 2001) (n.d.) ('Rivers, harbors, and public highways belong to all persons in common ....”).

24. MARC Bloch, French RuRal History 183 (Janet Sondheimer trans., 1966) (citation and internal quotation marks omitted).

25. Ralph Pentland, Public Trust Doctrine-Potential in Canadian Water and Environmental Management, POLIS PROJECT ON ECOLOGICAL GOVERNANCE, POLIS DisCUSSION PAPER 1, 3 (June 2009), http://www.flowforwater.org/documents/public_trust_doctrine.pdf.

26. Martin v. Waddell, 41 U.S. 367 (1842).

27. Id. at 413 .

28. Ill. Cent. R.R. v. Illinois, 146 U.S. 387 (1892).

29. Sax, supra note 8, at 489; see also Charles F. Wilkinson, The Headwaters of the Public Trust: Some Thoughts on the Source and Scope of the Traditional Doctrine, 19 ENVTL. L. 425,452 (1989) (discussing the role of Illinois Central in the development of public trust doctrine in the United States).
} 
that the lands concerned were "held in trust for the people of [Illinois]," and that the public "may enjoy the navigation of the waters, carry on commerce over them, and have liberty of fishing therein freed from the obstruction or interference of private parties. ${ }^{\prime 30}$ The Court further held that the grant of public land had resulted in "substantial impairment of the public interest" by excluding the public at large from having free and unimpeded access to, and use of, the land. ${ }^{31}$

Following Illinois Central, courts often invoked the public trust doctrine to keep natural resources, such as waterways, available to the public for economic activities including navigation, commerce, and fishing. The post-Illinois Central decisions, therefore, were largely geared toward the need to promote economic development in different regions of America. ${ }^{32}$

\section{The New Vision of the Doctrine}

Joseph Sax's 1970 Michigan Law Review article marked a paradigm shift in the public trust doctrine from its economic development-centric mode. With the rise of the modern environmental movement in the 1960s, Sax revitalized the public trust doctrine by unleashing its potential for protecting natural resources. In doing so, he imbued the public trust doctrine with new elements of substantive and procedural underpinnings.

In terms of the substantive value, Sax argued that the public trust doctrine should not be restricted to its conventional role in protecting the right of navigation, commerce, and fishing. Rather, the doctrine could act as a powerful legal tool for people to protect their right to sustainable protection of the environment. ${ }^{33} \mathrm{He}$ proposed that the public right to preservation of certain natural resources should be protected by the doctrine in the following three ways: first, "that certain interests are so intrinsically important to every citizen that their free availability tends to mark the society as one of citizens rather than of serfs;" 34 second, "that certain interests are so particularly the gifts of nature's bounty that they ought to be reserved for the whole of the

30. Ill. Cent. R.R., 146 U.S. at 452.

31. Id. at 453 .

32. See Molly Selvin, The Public Trust Doctrine in American Law and Economic Policy, 1789 1920, 1980 WIS. L. REV. 1403, 1404-05 (1980) (noting that "the public trust doctrine evolved as one of the most durahle [sic] tools for state intervention in and regulation of economic growth" in the postIllinois Central era).

33. See Sax, supra note 8, at 478-89. See also Joseph L. SAX, DefEnding The EnVIRONMENT: A STRATEGy For Citizen ACTION 158-74 (1971).

34. Sax, supra note 8, at 484. 
populace," $" 35$ and finally, "that certain uses have a peculiarly public nature that makes their adaptation to private use inappropriate."

With regard to the procedural value, Sax proposed that the public trust doctrine should be used to combat problems in the management of certain natural resources by the government. He discovered that the governmental management of natural resources is vulnerable to lobbying efforts made by interest groups. Thus, the decisions made by government can be skewed by the lobbying efforts, leading to harm to the public interest. To correct this problem, Sax contended that the public trust doctrine should procedurally empower courts to act on citizens' behalf to override any unreasonable privatization of natural resources carried out by government. ${ }^{37}$

In order to fulfill its substantive and procedural promises, the modern public trust doctrine, according to Sax, must be imbued with three interrelated standards of review: (1) "contain[ing] some concept of a legal right in the general public," (2) "be[ing] enforceable against the government," and (3) "be[ing] capable of an interpretation consistent with contemporary concerns for environmental quality." 38 With the surge of the environmental movement, Sax's theory of the public trust doctrine has provided a legal cause of action for public interest activists and citizens at large to prevent or stop environmental harm caused to certain natural resources. Inspired by Sax's groundbreaking thoughts, many courts relied on the public trust doctrine to defend the public interest in the preservation and protection of natural resources.

4. Expansive Application of the Doctrine through Statutorization and Judicial Decisions

As shown above, before the rise of the environmental movement in the early 1970 s, the public trust doctrine was largely used to protect the public interest in the utilitarian functions of natural resources for economic development. The application of the doctrine focused on ensuring public access to natural resources for navigation, commerce, or fishing, which were indispensable for economic activities. In accordance with these utilitarian functions, the resources held under public trust generally include navigable waters and land submerged under water.

With the rise of the environmental movement and the growing influence of Joseph Sax's pioneering visions, court decisions gradually transformed the

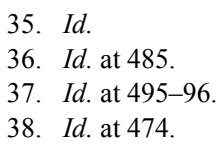


doctrine into a legal tool that broadly protects the public interest in the ecological and recreational functions of public resources. For example, the doctrine has been expanded to support the claims for preserving water resources, ${ }^{39}$ forests, ${ }^{40}$ and wildlife. ${ }^{41}$ Courts ruled in many cases that the residents' access to and recreational use of public parks must be ensured under the doctrine. ${ }^{42}$ The protected recreational uses also include public access to the beachfront for activities such as swimming, surfing, and sunbathing.

Meanwhile, the legal status of the public trust doctrine has been formally recognized in many state constitutions and both federal and state environmental statutes. ${ }^{43}$ For example, in honor of the nation's first celebration of International Earth Day, the Pennsylvania Legislature adopted section 27 of their constitution, which provides that "public natural resources are the common property of all the people, including generations yet to come. As trustee of these resources, the Commonwealth shall conserve and maintain

39. See, e.g., Nat'l Audubon Soc. v. Super. Ct. of Alpine Cnty., 658 P.2d 709, 719 (Cal. 1983); In re Water Use Permit Applications, 9 P.3d 409, 445 (Haw. 2000).

40. See, e.g., Avoyelles Sportsmen's League, Inc. v. Marsh, 715 F.2d 897 (5th Cir. 1983).

41. See, e.g., Geer v. Connecticut, 161 U.S. 519, 526-29 (1896) (tracing the common law roots and modern evolution of the soverign "right ... to control and regulate the common property in game" under "a trust for the benefit of the people"); see also Blake Hudson, The Public and Wildlife Trust Doctrines and the Untold Story of the Lucas Remand, 34 ColuM. J. ENVTL. L. 99 (2009) (highlighting how the public trust doctrine can be used against takings challenges); Gary D. Meyers, Variation on a Theme: Expanding the Public Trust Doctrine to Include Protection of Wildlife, 19 EnVTL. L. 723, 724 (1989) (arguing that the public trust doctrine should be expanded to include wildlife and its habitat).

42. See, e.g., Paepcke v. Pub. Bldg. Comm'n, 263 N.E.2d 11, 18 (Ill. 1970) (holding that the public trust doctrine prevents the sale of a park); Friends of Van Cortlandt Park v. City of New York, 750 N.E.2d 1050, 1055 (N.Y. 2001) (holding construction of water treatment plant in a city park required state legislative approval). See also Karl P. Baker \& Dwight H. Merriam, Indelible Public Interests in Property: The Public Trust and the Public Forum, 32 B.C. ENVTL. AfF. L. REV. 275, 285-90 (2005) (employing a comparative analysis to better understand the relationship between government and the "unorganized public" with respect to publically-owned property); Mackenzie Keith, Judicial Protection for Beaches and Parks: The Public Trust Doctrine Above the High Water Mark, 16 Hastings W.-Nw. J. ENVTL. L. \& POL'Y 165, 168 (2010) (arguing "courts can protect public recreational interests by ensuring public access to upland beaches and by preventing government management decisions that curtail the public's recreational use of upland parklands"); Serena M. Williams, Sustaining Urban Green Spaces: Can Public Parks Be Protected Under the Public Trust Doctrine?, 10 S.C. ENVTL. L.J. 23, 34-35 (2002) (arguing that public parks should be protected under the public trust doctrine).

43. See Alexandra B. Klass, Modern Public Trust Principles: Recognizing Rights and Integrating Standards, 82 NOTRE DAME L. REV. 699, 714 (2006) ("The environmental movement of the 1970s and Sax's article led not only to a resurgence in use of the common law public trust doctrine to protect natural resources and the environment but also to efforts to amend state constitutions to codify the public trust doctrine or create new constitutional rights to a clean or healthful environment."); Barton $\mathrm{H}$. Thompson, Jr., Environmental Policy and State Constitutions: The Potential Role of Substantive Guidance, 27 RUTGERS L. J. 863, 864 (1996) (cataloging various forms of public trust-like protections in state constitutions). See also Matthew Thor Kirsch, Upholding the Public Trust in State Constitutions, 46 DUKE L.J. 1169 (1997) (discussing the adoption of constitutional and statutory provisions in various states). 
them for the benefit of all the people."44 Other states paralleled Pennsylvania's course, enshrining various forms of the public trust idea in their constitutions. For example, Montana's constitution, approved in 1972, moves this agenda even further. It provides an "inalienable right[]" to a "clean and healthful environment" $" 45$ and creates a duty upon both the state and private persons to "maintain and improve a clean and healthful environment in Montana for present and future generations." the legislature "provide for the administration and enforcement of this duty" and "provide adequate remedies for the protection of the environmental life support system from degradation and provide adequate remedies to prevent unreasonable depletion and degradation of natural resources." 47

Moreover, a variety of state and federal environmental statutes have embraced the idea of public trust as the foundation of their legislative purpose and principle. This is probably the most important achievement of the environmental movement, because these statutes set up a comprehensive and detailed framework for environmental regulation. For instance, the Connecticut Environmental Protection Act, passed in 1971, includes a declaration of policy that "the air, water and other natural resources of the state of Connecticut" are held in public trust. ${ }^{48}$ In New York, General City Law provides that " $[\mathrm{t}]$ he rights of the city in and to its water front, ferries, wharf property, bridges, land under water, public landings, wharves, docks, streets, avenues, highways, parks, waters, waterways and all other public places are hereby declared to be inalienable[.] ${ }^{, 49}$

At the federal level, comprehensive federal environmental statutes and the agencies to implement them through regulation and enforcement have been created gradually. Many of these statutes, particularly the National Environmental Policy Act, the Clean Water Act, and the Endangered Species Act, are based on public trust doctrine. This is because these federal statutes set out a policy of protecting and preserving the environment for both the current and future generations.

44. PA. CONST. art I., $\S 27$.

45. MONT. CONST. art. II, $\S 3$.

46. Id. at art. IX, § 1 .

47. $I d$.

48. Conn. Gen. Stat. AnN § 22a-15 (1971). The declaration of policy states: "It is hereby found and declared that there is a public trust in the air, water and other natural resources of the state of Connecticut and that each person is entitled to the protection, preservation and enhancement of the same. It is further found and declared that it is in the public interest to provide all persons with an adequate remedy to protect the air, water and other natural resources from unreasonable pollution, impairment or destruction." Id..

49. N.Y. CITY CHARTER ch. 15, § 383 (2004), available at http://www.nyc.gov/html/charter /downloads/pdf/citycharter2004.pdf. 


\section{B. The Great Debate about the Public Trust Doctrine}

While the public trust doctrine has evolved into an important tool for protecting public resources, its foray into ecological preservation and recreational uses has turned out to be controversial on multiple fronts of the law and policy debate. Kearney and Merrill encapsulate the controversies that surround the public trust doctrine as follows:

The public trust doctrine has always been controversial. The general rule in American law favors ownership of natural resources as private property. The public trust doctrine, a jarring exception of uncertain dimensions, posits that some resources are subject to a perpetual trust that forecloses private exclusion rights. For environmentalists and preservationists who view private ownership as a source of the degradation of our natural and historical resources, the public trust doctrine holds out the hope of salvation through what amounts to a judicially enforced inalienability rule that locks resources into public ownership. For those who view private property as the bulwark of the free enterprise system and constitutional liberty, the doctrine looms as a vague threat. ${ }^{50}$

At the heart of the hostility toward the public trust doctrine, as Kearney and Merrill indicate, lies a central critique that sees the idea of public trust as inherently threatening to the stability of the private property-based democracy that is the foundation of individual liberty and security. From this perspective, opponents attacked the doctrine based on Sax's ideas primarily in two ways. First, the public trust doctrine is, by nature, a judicially-created and enforced tool that empowers the judiciary to threaten, disrupt, and even overturn legislative and administrative decisions to regulate public resources and protect private property. Led by Professor James Huffman, a long-time critic of the doctrine, commentators asserted that "the doctrine often permits nondemocratic courts to overrule the decisions of theoretically democratic legislatures. Thus, Sax's argument fails to justify the public trust doctrine in the context of American constitutional democracy." 51

Second, opponents argued that the public trust doctrine enables judicially-backed state actions that seize private property without

50. Joseph D. Kearney \& Thomas W. Merrill, The Origins of the American Public Trust Doctrine: What Really Happened in Illinois Central, 71 U. CHI. L. REV. 799, 800 (2004) (internal citations omitted).

51. Huffman, A Fish Out of Water, supra note 17, at 565. 
compensation. This runs directly counter to the Fifth Amendment, which clearly prohibits abuse of this governmental power. McQueen v. South Carolina Coastal Council ${ }^{52}$ illustrates the power of the public trust doctrine in defeating the Fifth Amendment claims. In that decision, the South Carolina Supreme Court held that no unconstitutional taking occurred when the state Coastal Council denied a permit application from McQueen to build a bulkhead and fill tidelands on what had earlier been his two residential lots. According to the court's ruling, the public trust doctrine places "a restriction on McQueen's property rights inherent in the ownership of property bordering tidal water." ${ }^{, 53}$ Such increased use of the public trust doctrine as a principle against the invocation of the Fifth Amendment caused an angry outcry. ${ }^{54}$ Opponents claimed that "private property rights are either compromised or eliminated altogether without any Fifth Amendment compensation." ${ }^{, 55}$ More broadly, the weakening of the Fifth Amendment gave rise to the concern that the public trust doctrine would seriously undermine private property protection in the long run. Thus, commentators contended that "any expansion of the public trust doctrine will narrow the remaining scope of private property and transfer more power to government." 56

Apart from the private property-based critiques of the doctrine's antidemocratic pedigree, opponents also discredit the doctrine as a narrowminded and obsolete vehicle for environmental protection. To them, the variegated web of legislative and administrative efforts have already created a comprehensive and advanced regulatory system to protect the environment. This system has demonstrated increasing sensitivity to, and capability in, environmental concerns and problems. By contrast, the judiciary lacks the necessary expertise to address the environmental problems that have become increasingly complex. Therefore, judge-made law and decisions will not be able to manage the systematic protection of the environment. Heavy reliance on the public trust doctrine, commentators

52. McQueen v. South Carolina Coastal Council, 580 S.E.2d 116 (S.C. 2003).

53. Id. at 120 .

54. Palazzolo v. State, No. 88-0297, 2005 R.I. Super. LEXIS 108, 1 at *27-38 (R.I. Super. Ct., 2005) (public trust doctrine can block a tidelands development without compensation); see also Michael C. Blumm \& Lucas Ritchie, Lucas's Unlikely Legacy: The Rise of Background Principles as Categorical Takings Defenses, 29 Harv. Envtl. L. Rev. 321 (2005); Erin Ryan, Palazzolo, The Public Trust, and the Property Owner's Reasonable Expectations: Takings and the South Carolina Marsh Island Bridge Debate, 15 SOUTHEASTERN ENVTL. L.J. 121, 146 (2006).

55. Smith \& Sweeney, supra note 17, at 333. See also Huffman, A Fish Out of Water, supra note 17, at 528 (arguing that "much of modern public trust law infringes upon vested private property rights and is therefore violative of the federal constitution"); James L. Huffman, Background Principles and the Rule of Law, 35 ECOLOGY L.Q. 1, 27 (2008).

56. SimMONS, supra note 19, at 17. 
warned, would even yield more undesirable results and social conflict, in that its outdated visions make the doctrine itself more vulnerable to the private property-based critiques:

Continued use of the doctrine ultimately threatens to impede environmental protection and resource conversation goals and possibly render Pyrrhic earlier advances. Most fundamentally, the doctrine's operation exacerbates a growing clash in liberal ideology within natural resources law-between the need for individual autonomy and security, traditionally tied up in private property rights, and the demands of longer-term collectivist goals expressed in environmental protection and resource conservation laws. $^{57}$

Central to the attacks on the public trust doctrine are doubts about the flexible, ad hoc approach that the doctrine embraces to address complex social issues of resource protection and preservation. The first type of criticism, as shown above, is based on an ideology that gives primacy to private property protection. The second type of criticism targets the perceived lack of judicial expertise to address increasingly complex environmental problems. Both types of attacks, however, come together to exhibit a strong distrust of decisions made by judges in a case-by-case and piecemeal manner. The judicially-centered approach, in the critics' view, lacks adequate predictability and stability in protecting both private property and public resources.

Despite the waves of attacks on the public trust doctrine from various fronts, the doctrine itself has been active and effective in fulfilling its underlying promises and goals of defending public resources. A search in the LexisNexis database in August 2010 showed that there were about 720 federal and state cases that dealt with the public trust doctrine. The latest Supreme Court decision on the doctrine is Phillips Petroleum Co. v. Mississippi ${ }^{58}$ which was decided in 1988. The latest federal circuit court decisions are Stockton East Water District v. United States ${ }^{59}$ and Abbey Co., LLC v. Lexington Insurance Co., ${ }^{60}$ which were decided in 2009 and 2008 respectively. Therefore, the doctrine has been actively used by both the federal and state courts. Moreover, there still remains a strong tendency to broadly apply the doctrine to defend the public trust resources for the

57. Lazarus, supra note 18 , at 692.

58. Phillips Petroleum Co. v. Mississippi, 484 U.S. 469 (1988).

59. Stockton East Water Dist. v. United States, 583 F.3d 1344 (Fed. Cir. 2009).

60. Abbey Co., LLC v. Lexington Ins. Co., 289 F. App'x. 161 (9th Cir. 2008). 
purpose of environmental protection, recreational use, and political engagement. In academia, there have been more proposals to use the doctrine to address other social issues such as cultural heritage preservation, the radio spectrum, intellectual property, and so on. ${ }^{61}$

These success stories raise the question as to why there has been a continued expansive use of the public trust doctrine on various fronts in spite of the waves of attacks that have been launched against it. The merits of any legal rules or standards, after all, largely rely on the extent to which they are capable of responding to their critics by demonstrating how they can ward off the undesirable social outcomes that the critics predict. It is through responding to criticisms that our legal rules or standards become more theoretically convincing and practically workable.

While the courts' decisions and the realities of environmental protection have shown the success of the public trust doctrine, the proponents of the doctrine have not yet come up with a comprehensive and systematic response to the attacks on the doctrine. Sax, the founder of the modern theory of the public trust doctrine, has not yet taken the lead to do so. The core idea of the public trust doctrine still remains the judicial intervention model. As Sax proposed in 1970, "[w] hen a state holds a resource which is available for the free use of the general public, a court will look with considerable skepticism upon any governmental conduct which is calculated either to reallocate that resource to more restricted uses or to subject public uses to the self-interest of private parties." ${ }^{20}$ His subsequent works calling for expansive use of the public trust doctrine have generally repeated his pioneering article by making the judiciary the center of the doctrine. For example, in his call to liberate the public trust doctrine from its "[h]istorical [s]hackles," Sax still emphasized the role of the judiciary as the central power in moving the environmental movement forward. ${ }^{63}$

Meanwhile, Sax's followers who have defended the doctrine still present it as a tool for judicial intervention in governmental decisions regarding management of public trust resources. ${ }^{64}$ For instance, by drawing on the process theory of judicial review, ${ }^{65}$ William Araiza argued that the

61. See supra text accompanying notes 11-13.

62. Sax, supra note 8, at 490 (emphasis omitted).

63. Joseph L. Sax, Liberating the Public Trust Doctrine from Its Historical Shackles, 14 U.C. DAVIS L. REV. 185, 193-94 (1980) [hereinafter Sax, Liberating the Public Trust Doctrine].

64. See, e.g., David B. Hunter, An Ecological Perspective on Property: A Call for Judicial Protection of the Public's Interest in Environmentally Critical Resources, 12 HARV. ENVTL. L. REV. 311, 368-70 (1988) (discussing the judicial intervention aspect of the public trust doctrine in the context of Illinois Central, among other perspectives); Wilkinson, supra note 7, at 277 (examining the potential role for the public trust doctrine in judicial review of public land management decisions).

65. See John Hart Ely, Democracy and Distrust: A Theory of Judicial Review 100-01 
invocation of the public trust doctrine should be seen as the "Court's attempt to find a role for judicial review within a democracy by focusing on the clearing of channels by which citizens exercise political power."

Yet the central problem in the judicial intervention model as championed by Sax and his followers is that it indeed invites skepticism about judiciary supremacy in protecting the public resources and the attendant risk of jeopardizing private property. Critics have been bombarding the expanding application of the doctrine with questions such as: Why are the courts empowered to be the leading force to protect public resources? Why can't we let the democratically formed legislatures or administrative agencies play the central role in tackling the myriad of issues concerned with environmental protection? What is the relationship between private property and public interests in public resources? Could the public interests necessarily gain primacy over private property? Therefore, for the proponents of the doctrine, substantial questions still loom large and the substantive values of the doctrine still await exploration. No wonder commentators claim that the public trust doctrine is little more than a "simple, easily understood, and intuitively appealing approach to environmental protection. ${ }^{, 67}$ To respond to the attacks, we need to respond to questions such as: What are the fundamental values that undergird the public trust doctrine and how can we achieve them in practice? Moreover, if there are any fundamental values, would they necessarily lend support to a public trust regime that is centered on judicial intervention?

In the following two parts of this Article, I will argue that we can make a comprehensive and systematic response to criticisms leveled against the public trust doctrine by revisiting the fundamental value that undergirds the doctrine. To this end, I will put forth that the fundamental value of the doctrine lies in its role of protecting a vibrant public space that is essential

(1980) (arguing that the Court should devote itself to assuring majority governance while protecting minority rights). For example, Ely points out that "[t]he Constitution has ... proceeded from the ... sensible assumption that an effective majority will not inordinately threaten its own rights, and has sought to assure that such a majority not systematically treat others less well than it treats itself - by structuring decision processes at all levels to try to ensure, first, that everyone's interests will be actually or virtually represented (usually both) at the point of substantive decision, and second, that the processes of individual application will not be manipulated so as to reintroduce in practice the sort of discrimination that is impermissible in theory." Id.

66. William D. Araiza, Democracy, Distrust, and the Public Trust: Process-Based Constitutional Theory, the Public Trust Doctrine, and the Search for a Substantive Environmental Value, 45 UCLA L. REv. 385, 389 (1997). For a similar defense, see Barton H. Thompson, Jr., The Public Trust Doctrine: A Conservative Reconstruction \&. Defense, 15 SOUTHEASTERn ENVTL. L.J. 47, 51 (2006).

67. Richard Delgado, Our Better Natures: A Revisionist View of Joseph Sax's Public Trust Theory of Environmental Protection, and Some Dark Thoughts on the Possibility of Law Reform, 44 VAND. L. REV. 1209, 1210 (1991). 
for human development. It is the collective enterprise of maintaining and enhancing the robustness and vitality of public space that makes the public trust doctrine an indispensable legal tool for human flourishing and social development.

To be sure, I do not mean that Sax and his followers do not have any valid responses to the changes in the public trust doctrine and the ways it resurrected itself from the waves of attacks. Instead, I believe that they have not gone far enough to defend the doctrine.

\section{The Public TRust Principle of Protecting the Fundamental RightS OVER PUBLIC SPACE}

In this Part, I will put forward a new social-political theory of the public trust doctrine that is capable of rendering a comprehensive and systematic response to the attacks against the doctrine. I will argue that we can reconceptualize the theoretical and policy foundation of the doctrine by considering the indispensable role of public space in human development. In my view, the public trust doctrine plays a critically important role in protecting the vitality of public space, which is core to human development. From this perspective, the doctrine is a solid legal mandate for protecting public space and promoting public freedom. Moreover, the expansive use of the public trust doctrine has reshaped the doctrine as a constitutional principle that undergirds the protection of citizens' fundamental rights over public space. Working in this way further shapes the doctrine itself to fill a loophole in our Constitution, which has been largely designed to protect the private sphere as the foundation of citizens' private rights. The new foundation of the doctrine, as I will show, not only helps the public trust protagonists to defend the desirability of the doctrine, but also affords us with a better-informed vision of the role of the doctrine in promoting individual, as well as social, well-being.

\section{A. The Role of Private and Public Space in Human Development}

Having a private space is of essential importance for every human being to achieve self-development and to flourish. The private space that belongs exclusively to a particular person draws the boundaries of the sphere, such as walls, fences, and doors. In this way, it affords a bounded sphere in which we are left free to choose our own ways of satisfying our desires and inclinations without undesirable interventions from others. In our own private spaces we remain free to design the contents of private life as individuals. We cook, eat, and sleep. We enjoy happiness and peace with family members and friends. 
We can even choose to live through loneliness or sorrow. Even Hegel, although he was a crucial figure in inspiring modern communitarianism, attached great importance to the role of private space in fostering individual self-consciousness, personality, and worldview, which are all vital to human development. Hence, he states that "[t]he person must give himself an external sphere of freedom in order to have being as Idea."68 A more thorough pronouncement of the role of private spaces in human development can be found in Hannah Arendt's works. As a legendary thinker on the human condition, she asserted that "to have no private place of one's own (like a slave) meant to be no longer human." 69

Yet having private space is not the only condition by which we achieve self-development and flourishing. The human condition, in fact, constantly entails direct or indirect influences from others. For example, our ability to speak a language, one of the basic human capabilities, is acquired through numerous encounters and interactions with others. Although parents surely play an important role in nurturing our linguistic capabilities in the family setting, we sustain and enhance them through speaking with and listening to people whom we meet on various occasions. Furthermore, our exposure to the general cultural environment improves our linguistic capabilities, because it provides us with the multitude of social norms that govern the ways in which people speak. These social norms are, by nature, collectively shaped by the people who live in the same community. Therefore, the role of "others" in human development, direct or indirect, shows that human action and speech, as Hannah Arendt observed, are "never possible in isolation" and "need the surrounding presence of others." "70

In addition to the "human" other, we also need non-human objects as the "other" for our development and flourishing. Things like houses, beds, and clothes form the external sphere that is essential to our life in our private space. Meanwhile, there are non-human objects that constitute the indispensable "other" outside the boundaries of private spaces. On the one hand, we can find our presence, be it constant or sporadic, in the non-human "other" that is not made by men. We go boating on the river, hiking in the

68. G. W. F. Hegel, Elements of THE Philosophy of Right § 41, at 73 (Allen W. Wood ed., H. B. Nisbet trans., 1991). For interpretation of Hegel's theory of property, see Haochen Sun, Designing Journeys to the Social World: Hegel's Theory of Property and His Noble Dreams Revisited, 6 Cosmos \& Hist.: J. NAT. \& SOC. PHIL. 33, 33-34 (2010), available at http://www.cosmosandhistory.org/index.php/journal (Click "current issue" or "2010").

69. Hannah Arendt, The Human Condition 64 (2d ed. 1998). See also Margaret Jane Radin, Property and Personhood, 34 STAN. L. REV. 957, 957 (1982) (arguing that owning private property is essential for developing personhood).

70. ARENDT, supra note 69, at 188. Arendt also points out that "action and speech are surrounded by and in constant contact with the web of the acts and words of other men." Id. 
mountains, and picnicking in the forest. In our eyes, these things, the nonman-made "other," form the natural environment to which we belong. ${ }^{71}$ On the other hand, we can find our presence in the "other" that is made collectively by our fellow human beings. We speak loudly in the town square, drive freely on the highway, and play happily in the park. These venues, the man-made "other," form the social environment in which we are nurtured. Whether man-made or not, all these "others" create the environment that lies outside the boundaries of our private spaces. ${ }^{72}$

This role of "others" in human development ${ }^{73}$ makes it impossible for any of us to live only within the closed boundaries of our own private spaces. Rather, because the "other" always physically exists outside of the private space, a person's coming to the "other" requires him to situate himself in the place where he and the "other" can meet each other, though the distance between them is not constant (sometimes face-to-face, sometimes not). This arena is the public place where only open boundaries exist.

Basically, the openness of public space that accommodates "me" and "others" has two core attributes: publicity and commonality. First, public

71. See FranÇOIS Leydet, The LaSt Redwoods 132 (1969) (“'[M]an does not live by bread alone. He has needs that are no less real and no less vital — although they are harder to measure in economic terms - than food and water and shelter. He has a thirst for beauty. He often has a hunger for solitude. $\mathrm{He}$ craves the companionship of other animal species. He has a deep, atavistic urge for identification with nature. Witness the extraordinary upsurge of hiking and camping and boating and the overwhelming increase in use of our natural parks."); JAMES SALZMAN \& BARTON H. THOMPSON, ENVIRONMENTAL LAW AND POLICY 3 (2003) ("The stillness of a remote forest lake or the imposing crags of a mountain peak provide for many both a sense of connection to a larger world and a sense of inner wonder.").

72. See George Herbert Mead, Mind, Self, \& Society 135 (Charles W. Morris ed., University of Chicago Press, 15th impression, Phoenix Books 1967) (1934) (using the language process as an example to demonstrate that the self "arises in the process of social experience and activity, that is, develops in the given individual as a result of his relations to that process as a whole and to other individuals").

73. The phenomenologist account of human development offers the most profound discussion about the relationship between the self and the other. See, e.g., G. W. F. HEgEL, PHENOMENOLOGY OF SPIRIT $\S 178$, at 11 (A. V. Miller trans., 1977) ("Self-consciousness exists in and for itself when, and by the fact that, it so exists for another; that is, it exists only in being acknowledged."); EMMANUEL LEVINAS, TOTALITY AND INFINITY: AN ESSAY ON EXTERIORITY 193 (Alphonso Lingis trans., Duquesne University Press 1969) (1961) ("It is the face; its revelation is speech. The relation with the Other alone introduces a dimension of transcendence, and leads us to a relation totally different from experience in the sensible sense of the term, relative and egoist."). The idea of men as social beings further lends a strong support to the phenomenologist account of human development. See ARISTOTLE, The Nicomachean Ethics 12 (David Ross trans., Oxford University Press ed. 1980) ("[B]y self-sufficient we do not mean that which is sufficient ... for one who lives a solitary life, but also for parents, children, wife, and in general for his friends and fellow citizens, since man is born for citizenship."); ARISTOTle, Politics 10 (Oxford 1998); Roberto MANGabeira UNGER, KNOWLEDGE AND POLITICS 216 (1975) ("[L]ike everything else the self is defined by the totality of its relations with other beings and, particularly, with other selves."); Karl Marx, Economic Philosophic Manuscripts of 1844, in 66 THE MARX-ENGELS READER 85 (Robert C. Tucker ed., W.W. Nortan \& Company 1978) (1844) ("[T] he human essence of nature first exists only for social man; for only here does nature exist for him as a bond with man - as his existence for the other and the other's existence for him - as the life-element of the human world. ..."). 
space is the open arena where "everything that appears in public can be seen and heard by everybody and has the widest possible publicity." 74 Once we enter into public spaces, it is inevitable that we expose ourselves to others though the means and degree of self-exposure are varied depending on circumstances. Our body movements, our voices, or even our thoughts are seen, heard, or learnt by the mass public. In public space, all our actions carry this sort of communicative function. ${ }^{75}$

Second, public space is the open arena where people have things together in common and these things are not held in exclusive possession by any single person. ${ }^{76}$ A public park, for example, is a place where all people, regardless of their income or residency in the country, can enter and enjoy its environment. This is because we treat the public park as a common resource and each of us is entitled to have access to and make use of it. More broadly, public space is the open arena where people map out their common goals and aspirations for a community, a country, or even the whole of humanity. In places such as streets, squares, and town halls, we hold discussions or debates about the issues associated with human interactions in society. Through interactions with one another, we gradually develop the common language we may use and the common identity that we choose to belong to. Therefore, public space affords us with the common sphere in which we can meet and act together to achieve social, cultural, or political agendas.

The attributes of both publicity and commonality clearly show that preserving the openness of public space is essential for developing the public freedom we must have for human development. Public freedom is concerned with the well-being of the people as a whole and the degree to which public space can contribute to it. Manipulation of any parts of public spaces dilutes its publicity and commonality. For example, the use of violence in or exclusive dominance over places like a public square is damaging to public freedom. Therefore, both private space and public space are essential for human development. While private space provides the necessary peace and security for an individual to achieve self-actualization and self-fulfillment, public space furnishes individuals with the indispensable vehicle for becoming members of a society and also provides a dynamic contextual environment for individuals to develop their individualities and personalities through their

74. ARENDT, supra note 69 , at 50. A similar notion of the publicity is offered by Iris Young. See IRIS MARION YOUNG, INCLUSION AND DEMOCRACY 168-70 (2000).

75. See JÜrgen Habermas, The Structural Transformation of the Public Sphere: An INQUIRY INTO A CATEGORY OF BOURGEOIS SOCIETY 27 (Thomas Burger trans., 1989) (noting that as performing of all communicative actions is done in a public setting, it necessarily involves "people's public use of their reason").

76. ARENDT, supra note 69 , at 52. 
private spaces. There is a cross-fertilizing and mutually interdependent relationship between the private and public spheres. Habermas captures the essence of the relationship by concluding that "[a] well-secured private autonomy helps 'secure the conditions' of public autonomy just as much as, conversely, the appropriate exercise of public autonomy helps 'secure the conditions' of private autonomy."77

\section{B. The Asymmetry of Legal Protections of Private Spaces and Public Spaces}

While the private sphere and public sphere are of equal significance for human development, our legal system, in particular the U.S. Constitution, provides relatively less protection for the human interest in public space. While the Constitution has been largely designed to afford strong protection of individuals' rights over the private space, it does not contain direct provisions affording the public rights over public space.

Heavily influenced by liberalism and its prioritizing of individual liberty and freedom, ${ }^{78}$ the Constitution has been geared to safeguard the security and stability of the private space of individuals. To this end, it lays out the fundamental rights that individuals ought to enjoy and sets limits within which the government can exercise its power over these fundamental rights.

Constitutionally protected rights such as property rights ${ }^{79}$ and privacy rights ${ }^{80}$ all safeguard what a person decides to do in his or her private space in order to prevent or stop undesirable interference from others. Fundamental rights of this type empower persons to gain full control of their bodies and lives, and also enable them to design their individualities and plans to pursue lives of their own. From this perspective, other fundamental rights, including the freedom of expression, the freedom of religion, and the freedom of association are largely extensions of what we do in our private spaces. They further reinforce our ability to decide what to do in our private spaces with the benefit of our experiences gained in exercising these rights. In fact, the need to protect individually-controlled private spaces with fundamental rights was clearly stated in the Declaration of Independence: "We hold these truths to be self-evident, that all men are created equal, that they are endowed by their

77. JÜrgen Habermas, Between Facts And Norms: Contributions to a Discourse THEORY OF LAW AND DEMOCRACY 408 (1996) (internal citation omitted).

78. See, e.g., Sotirios A. Barber, Liberalism and the Constitution, 24 Soc. PHIL. \& POL'Y 234, 234 (2007) ("The U.S. Constitution is widely regarded as the preeminent historical expression of philosophical liberalism....”).

79. See U.S. CONST. amend. V ("[N] or shall private property be taken for public use, without just compensation.").

80. Griswold v. Connecticut, 381 U.S. 479, 484 (1965) ("Various guarantees [contained by the Constitution] create zones of privacy."). 
Creator with certain unalienable Rights, that among these are Life, Liberty and the pursuit of Happiness." $" 81$

To guarantee and reinforce the protection of fundamental rights, the Constitution itself carries a set of basic mandates that delimit the ways in which state institutions, namely the legislature and the executive branch, can exercise their power. These institutional designs ensure that each branch, which wield more resources than any individual, would not unduly intrude upon the private spaces that fundamental rights protect. ${ }^{82}$

Therefore, our Constitution is founded on the idea of protecting negative liberty, minimizing the government's undue interference into the private space of individuals. ${ }^{83}$ The combination of fundamental individual rights and the power-limiting mandates for the government aims to ensure the safety and stability of the private space in which we are left to pursue our own private freedom for human development. In traditional political theory, this institutional arrangement is regarded as a safeguard of negative liberties against undesirable interferences by other individuals or the government against a particular individual's exercise of freedom in his or her private space. $^{84}$

As shown in the first section of this Part, public space plays an equally important role in human development as private space. Despite the paramount importance of public space, there are, however, no direct and explicit measures adopted in the Constitution to maintain and promote the public space over which individuals as citizens ought to have rights to promote human development. Nor does the Constitution explicitly protect or preserve the resources that form and enhance public space. This gives rise to an inequality problem in the constitutional protection of human liberty: while

81. THE DECLARATION OF INDEPENDENCE para. 2 (U.S. 1776).

82. See, e.g., Keith E. Whittington, Constitutional Construction: Divided Powers and Constitutional Meaning 1 (1999) ("The Constitution is a governing document. It defines and constrains the way government operates and politics is conducted in the United States.").

83. See David Abraham, Liberty without Equality: The Property-Rights Connection in a "Negative Citizenship" Regime, 21 LAW \& SOC. INQUIRY 1, 4 (1996); Frank I. Michelman, Possession vs. Distribution in the Constitutional Idea of Property, 72 IowA L. REV. 1319, 1319 (1987) ("When we speak of constitutional protection for property rights, we think first of keeping, not having - of negative claims against interference with holdings, not positive claims to endowments or shares. Thus, we primarily understand property in its constitutional sense as an antiredistributive principle, opposed to governmental interventions into the extant regime of holdings for the sake of distributive ends."); Harry N. Scheiber, Public Rights and the Rule of Law in American Legal History, 72 CALIF. L. REV. 217, 218 (1984) ("Along with individual (personal) rights, such as those protected by the Bill of Rights, vested property rights were claims against government; they defined a zone of private action and uses of property into which governmental authority could not be allowed to penetrate.").

84. See Isaiah Berlin, Two Concepts of Liberty, in LIBERTY 166, 168-81 (2002) (explaining that negative liberty refers to the freedom without undue interference from the government, and positive liberty deals with the freedom derived from government plans and actions). 
individuals' negative liberties are protected as fundamental rights over private spaces, the Constitution does not explicitly protect individuals' interests over public spaces, which are equally important for human development.

The lack of any provisions protecting the environment, in fact, epitomizes the absence of explicit protection of rights over public space in the Constitution. It is now widely accepted that maintaining a clean and healthy environment is fundamentally important to both the well-being of individuals and to the society as a whole. In an International Court of Justice ruling, Vice President Weeramantry asserted that " $[\mathrm{t}]$ he protection of the environment is likewise a vital part of contemporary human rights doctrine, for it is a sine qua non for numerous human rights such as the right to health and the right to life itself." 85 While environmental protection is of vital importance for our survival and future development, the Constitution contains no explicit provisions that either delegate power to the federal and state governments to adopt environmental regulatory measures or afford any fundamental environmental rights to citizens, despite three unsuccessful amendment attempts between 1967 and 1970, and renewed efforts in $2003 .{ }^{86}$

But if we look abroad, it is easy to find that the environmental right is enshrined as one of the fundamental rights in international human right treaties and in the constitutions of many countries. ${ }^{87}$ Without affording such a public right, our Constitution, according to commentators, "is one of the few such texts in the world that fails to explicitly address environmental protection." $" 88$

Despite the structural asymmetry in the protection of rights in the United States, the constitutional protection of individual rights suggests that the law ought to recognize and defend interests that are fundamental to human development. The interest conception of rights has been systematized by Joseph Raz. He suggests that A has a right to X only if the interest A has in having $\mathrm{X}$ is a sufficient reason for imposing a duty on $\mathrm{B}$; conceptions of interests are determined by ultimate values. ${ }^{89}$ Raz's account thus allows for the derivation of both individual and collective rights from fundamental

85. Concerning the Gabiçíkovo-Nagymaros Project (Hung. v. Slovk.), 1997 I.C.J. 85, 91 (Sept. 25) (separate opinion of Vice President Weeramantry).

86. In 2003, Representative Jesse Jackson, Jr. introduced a constitutional amendment respecting "a right to a clean, safe, and sustainable environment." H.R.J. Res. 33, 108th Cong. (2003). See also David W. Orr, Law of the Land, ORION, Jan.-Feb. 2004, available at http://www.orionmagazine.org/ index.php/articles/article/133/ (arguing for a constitutional amendment guaranteeing a right to a healthy environment).

87. See Tim Hayward, Constitutional Environmental Rights 27-28, 55-58 (2005) (examining the protection of environmental rights under international treaties and state constitutions).

88. Douglas A. Kysar, Regulating From nowhere: Environmental LaW and the SEARCH FOR OBJECTIVITY 229 (2010).

89. Joseph RAZ, The Morality OF FreEdOM 180 (1986). 
interests. Individuals, he argues, have an interest in living in communities, and communities can have collective interests such as the interest in selfdetermination..$^{90}$ Therefore, following Raz's interest theory of rights, as long as we have an interest in the public space that is strong enough, legal protection must be afforded to protect the rights concerned with public space. If individuals' interests in private space can be protected as fundamental rights under the Constitution, individuals' interests in public space also deserve protection as fundamental rights. ${ }^{91}$

\section{Public Trust Doctrine as a Legal Tool to Defend Public Space}

Given the lack of explicit constitutional measures protecting individuals' interests in public space, the public trust doctrine has largely been used to close this loophole in the Constitution. In doing so, the public trust doctrine has been designed as the linchpin for recognizing and protecting the public's fundamental rights over public space. The doctrine performs this rightsconferring function primarily by holding certain resources in trust for the general public as a whole and thereby making them open to all. These resources are by nature regarded as "inherent public property," 92 and every member of the public has free and unimpeded access and use of them. The public ownership vested in the general public makes the boundaries of the public trust resources constantly open to everyone on equal terms, preserving and enhancing their attributes of public access and commonality. Therefore, the public trust doctrine is by nature designed to keep the protected resources open to every member of the public and to prevent them from being privatized or monopolized, with closed boundaries, by any private parties. ${ }^{93}$

Since Illinois Central was decided in $1892,{ }^{94}$ the public trust doctrine has conferred four kinds of fundamental rights upon individuals as members of the public. These rights are categorized as economic rights, ecological rights, cultural rights, and political rights. The fundamental rights protected by the public trust doctrine are reflective of individuals' economic, ecological,

90. Id.

91. Scheiber, supra note 83, at 219 (arguing that "it is mistaken ... to limit our understanding of rule of law in our constitutional and legal history so as to confine it altogether to notions of private claims against government").

92. Carol Rose, The Comedy of the Commons, Custom, Commerce and Inherently Public Property, 53 U. CHI. L. REv. 711, 720 (1986).

93. See id. at 774. Professor Rose pointed out that there are two essential elements in public property: "[F]irst, the property had to be physically capable of monopolization by private persons - or would have been without doctrines securing public access against such threats. Second, the public's claim had to be superior to that of the private owner, because the properties themselves were most valuable when used by indefinite and unlimited numbers of persons - by the public at large." Id.

94. See supra notes 28-31 and accompanying text. 
cultural, and political interests in using public spaces. Moreover, they are vital and crucial to economic, ecological, cultural, and political development of public space as a whole.

\section{The Right to Participate in Economic Activities in Public Space}

Historically speaking, the first category of rights protected by the public trust doctrine involves participation in economic activities in public space. This includes the rights to commerce, navigation, and fishing. It has been recognized that some resources such as waterways are vital to the economic development of the nation and to individuals' participation in economic activities such as transportation of raw materials and finished products. As Adam Smith pointed out, commerce requires the interaction of persons, and this requires access to certain physical locations, namely waterways and roads. ${ }^{95}$ Keeping public facilities such waterways, roads, and bridges open to the public is necessary for the transportation of goods and the movement of people involved in trade.

Dating back to the early nineteenth century, the Supreme Court in Martin v. Waddell addressed the public trust doctrine and its application to coastal lands. ${ }^{96}$ In that case, the Court declared that "the shores, and rivers, and bays, and arms of the sea, and the land under them ... [were] held as a public trust for the benefit of the whole community, to be freely used by all for navigation and fishery, as well as for shell-fish as floating fish." ${ }^{97}$ Later in Illinois Central, the Supreme Court drew on the collective-right approach to establish a new way of protecting the public interest in submerged lands, emphatically arguing as follows:

[The title to submerged lands] is a title different in character from that which the State holds in lands intended for sale. It is different from the title which the United States hold in the public lands which are open to preemption and sale. It is a title held in trust for the people of the State that they may enjoy the navigation of the waters, carry on commerce over them, and have liberty of fishing therein freed from the obstruction or interference of private parties. ${ }^{98}$

Therefore, according to Illinois Central, the submerged lands underneath Lake Michigan could never be monopolized by a single private party. The

95. AdAm Smith, The WeAlth of Nations 17-19, 682 (Modern Library ed. 1937).

96. Martin v. Waddell, 41 U.S. 367 (1842).

97. Id. at 413 .

98. Ill. Cent. R.R. v. Illinois, 146 U.S. 387, 452 (1892) (emphasis added). 
citizens' fundamental rights should not and cannot be relinquished by conveying the lands to a private party. By maintaining the openness of the waterways and the land underneath, the Court protected citizens' fundamental rights to participate in economic activities, allowing them to have equal access to and make unimpeded use of the public trust resources.

\section{The Right to Ecological Protection of Public Space}

Given the paramount importance of ecosystem preservation, the public trust doctrine has been widely used to afford citizens with the right to ecological protection of public space. ${ }^{99}$ The protection of rights of this type reflects the fact that individuals share a common interest in maintaining a healthy natural environment for all.

It has been long recognized that the natural environment is formed by interconnected ecosystems, so that all the parts of the natural environment are interdependent and cannot be reduced to disparate bits and pieces. ${ }^{100}$ The deterioration of the environment usually results from human activities that make undesirable alterations to the integrity of the environment. These activities are routinely performed by people in order to exploit a particular natural resource without paying sufficient heed to the negative impacts on the environment in its entirety.

Against this backdrop, the public trust doctrine functions to protect and preserve the natural environment by providing safeguards against "destabilizing changes"101 to natural resources that belong to the public space of the general public. In doing so, the doctrine supports the "land ethic" that is based upon the notion that "[a] thing is right when it tends to preserve the integrity, stability, and beauty of the biotic community. It is wrong when it

99. Nat'l Audubon Soc. v. Super. Ct. of Alpine Cnty, 658 P.2d 709, 719 (Cal. 1983) (quoting Marks v. Whitney, 491 P.2d 374, 380 (Cal. 1971)); Marks, 491 P.2d at 380. Almost all commentators maintain that the public has the right to environmental protection under the public trust doctrine. See, e.g., Sax, Liberating the Public Trust Doctrine, supra note 63, at 192-93 (discussing the public trust doctrine's role in ecological protection given important property considerations such as expectations and destabilization); Bernard S. Cohen, The Constitution, The Public Trust Doctrine, and the Environment, 1970 UTAH L. REV. 388, 393-94 (1970) (arguing that the right to a healthy environment stems from the interaction of the public trust doctrine with the Ninth Amendment); David Takacs, The Public Trust Doctrine, Environmental Human Rights, and the Future of Private Property, 16 N.Y.U. ENVTL. L.J. 711, 712 (2008).

100. See, e.g., Judy L. Meyer, The Dance of Nature: New Concepts in Ecology, 69 CHI.-Kent L. REV. 875, 883 (1994) ("Our history ... has taught us that activities in one part of the landscape greatly influence other parts.").

101. Sax, Liberating the Public Trust Doctrine, supra note 63, at 188. ("The central idea of the public trust is preventing the destabilizing disappointment of expectations held in common but without formal recognition such as title. The function of the public trust as a legal doctrine is to protect such public expectations against destabilizing changes, just as we protect conventional private property from such changes."). 
tends otherwise." $" 102$ It also mandates that members of the public cannot use natural resources in a completely unencumbered fashion. Rather, "conservation of resources is intrinsically good and necessary for the continuance of society." 103

Therefore, the public trust has been invoked as a powerful legal tool for combating manipulative activities that damage the natural environment, including, among many others, water pollution ${ }^{104}$ and trafficking in endangered species. ${ }^{105}$ The typical case is the use of the doctrine to fight unreasonable diversion of natural resources. For example, the California Supreme Court forbade the water department of Los Angeles to unreasonably divert water from the rivers feeding Mono Lake on the ground that the vast diverting of water had severely degraded the lake's scenic beauty and ecological values. ${ }^{106}$ Given that the lake waters are held in public trust for all the citizens in California, the State as the trustee of the water resources was deemed to have failed to "prevent[] any party from acquiring a vested right to appropriate water in a manner harmful to the interests protected by the public trust." 107

Moreover, by ruling out any unreasonable alterations to public trust natural resources, the doctrine recognizes and embraces the intrinsic values of maintaining the openness of the natural environment. The California Supreme Court, for example, emphasized the practice of conservation through keeping the tidelands open for all:

There is a growing public recognition that one of the most important public uses of the tidelands - a use encompassed within the tidelands trust - is the preservation of those lands in their natural state, so that they may serve as ecological units for scientific study, as open space, and as environments which provide food and habitat for birds and marine life, and which favorably affect the scenery and climate of the area. ${ }^{108}$

102. Aldo Leopold, A SAnd County Almanac 240 (4th ed. 1975).

103. W.J.F. Realty Corp. v. State, 672 N.Y.S.2d 1007, 1012 (N.Y. Sup. Ct. 1998)

104. See, e.g., Nat'l Audubon, 658 P.2d at 719; In re Water Use Permit Applications, 9 P.3d 409, 447 (Haw. 2000).

105. See, e.g., Geer v. Connecticut, 161 U.S. 519 (1896).

106. Nat'l Audubon, 658 P.2d at 714-16, 732. "As a result of these diversions, the level of the lake has dropped; the surface area has diminished by one-third; one of the two principal islands in the lake has become a peninsula, exposing the gull rookery there to coyotes and other predators and causing the gulls to abandon the former island. The ultimate effect of continued diversions is a matter of intense dispute, but there seems little doubt that both the scenic beauty and the ecological values of Mono Lake are imperiled." Id. at 711 .

107. Id. at 727 .

108. Marks v. Whitney, 491 P.2d 374, 380 (Cal. 1971) (emphasis added). 
This statement shows that the public trust doctrine fully recognizes interdependence of different elements of our natural environment.

\section{The Right to Cultural Participation in Public Space}

Culture is a product of collective human efforts in creating the behavioral modes in a society. ${ }^{109}$ Any cultural development stems first from socialization in public space, through which human beings exchange ideas in a variety of ways. The recreational use of public space is an important vehicle for human socialization. A person's participation in recreational activities in public space opens the door for him to mingle with others and to exchange thoughts and ideas with them. Moreover, it allows him to relax and improve his physical and mental well-being by taking part in those recreational activities with the company of other people in public space.

To enrich human socialization, the public trust doctrine has been designed to protect citizens' rights to cultural participation in public space. The doctrine mandates that certain natural resources should be kept open for the public to use for recreational activities. The recreational uses permitted and protected by the doctrine include bathing, swimming, walking, and so on. ${ }^{110}$ By keeping certain natural resources open for recreational use by the public, the doctrine encourages people to enter public space, and thereby promotes cultural participation by facilitating active socialization among people in public space. The Connecticut Supreme Court first expressly recognized that public trust rights protect a variety of recreational activities, including "boating, hunting, bathing, taking shellfish, gathering seaweed, cutting sedge, and ... passing and repassing" in the public trust resources. ${ }^{111}$ Generally speaking, there has been a solid recognition of the right of recreational use in many states, such as California, ${ }^{112}$ New Jersey, ${ }^{113}$ Washington, ${ }^{114}$ and Michigan, ${ }^{115}$ with a few exceptions. ${ }^{116}$

109. See, e.g., JERry D. MOORE, Visions OF CUlture: AN INTRODUCTION TO ANTHROPOLOGICAL THEORIES AND THEORISTS 54 (2009) (“[C]ulture consisted of learned and shared knowledge and behavior, expressed in such different ways as technology, social organization, or language.").

110. See generally Rose, supra note 92, at 777-81 (explaining the role of public property in facilitating socialization).

111. Town of Orange v. Resnick, 109 A. 864, 865 (Conn. 1920).

112. Marks, 491 P.2d at 380; Nat'l Audubon Soc'y v. Super. Ct. of Alpine Cnty., 658 P.2d 709, 719 (Cal. 1983).

113. Raleigh Ave. Beach Ass'n v. Atlantis Beach Club, Inc., 879 A.2d 112, 113 (N.J. 2005);

Matthews v. Bay Head Imp. Ass'n, 471 A.2d 355, 364 (N.J. 1984).

114. Orion Corp. v. State, 747 P.2d 1062, 1065 (Wash. 1987) (en banc).

115. Glass v. Goeckel, 703 N.W.2d 58, 62 (Mich. 2005). 
More importantly, the public trust doctrine carries a mandate to keep venues open to accommodate and facilitate recreational activities. By doing so, the doctrine keeps public spaces open for all and ensures that people are free to enter public spaces to interact and socialize with others. Under this doctrine, recreational uses of public venues, such as parklands, have been deemed crucial for the cultural development of human society. ${ }^{117}$

\section{The Right to Political Participation in Public Space}

The public trust doctrine embraces a strong protection of citizens' right to political participation in public space. Effective democratic governance necessarily entails citizens' active participation in public discourse on a wide range of social issues. To this end, the citizens at large must have the freedom to take part in "uninhibited, robust, and wide-open"118 debate in public space. By providing the venue for human interactions, the public trust doctrine fosters a culture of political participation, thus enriching human socialization and promoting democratic governance.

Under the public trust doctrine, public space ought to be kept open for everyone to express his or her views, to make suggestions, to exchange information, and to raise doubts. The openness of public space, in essence, allows people to speak freely in order to participate in democratic governance. For example, streets and parks are important venues for people to speak effectively in public space. Any interventions that limit the openness of streets and parks as public spaces would suppress free speech and impair the public's right to participate in democratic governance. Hence, courts have invoked the public trust doctrine to make sure that streets and parks as the public fora for free speech activities are open to all. For example, in Hague v. Committee for Industrial Organization, the Supreme Court famously stated

[W]herever the title of streets and parks may rest, they have immemorially been held in trust for the use of the public and, time out of mind, have been used for purposes of assembly, communicating thoughts between citizens, and discussing public questions. Such use of the streets and public places has, from ancient times, been a part of the privileges, immunities, rights, and liberties of citizens. ${ }^{119}$

116. The Massachusetts and Maine Supreme Courts refused to extend the public trust doctrine to recreational uses and strictly limited it to navigational and fishing purposes. See Opinion of the Justices, 365 Mass. 681, 688 (1974); Bell v. Town of Wells, 510 A.2d 509, 516, 519 (Me. 1986).

117. See Baker \& Merriam, supra note 42, at 299.

118. N.Y. Times Co. v. Sullivan, 376 U.S. 254, 270 (1964).

119. Hague v. Comm. for Indus. Org., 307 U.S. 496, 515 (1939). See also Frisby v. Schultz, 487 


\section{The Public Trust Doctrine as a Legal Tool to Enforce the Public Trust Principle}

As shown above, the public trust doctrine confers rights on individuals with respect to their interests in public space. This represents an indirect approach to address the asymmetrical problem in the negative liberty-oriented Constitution: while individual rights over private spaces are enshrined as fundamental rights, the same does not apply to public rights over public spaces.

I will argue in this Part that the use of the public trust doctrine through judicial decisions, legislative actions, administrative measures, and even public discourse, has developed a general principle in our legal system and constitutional protection of rights. The public trust principle mandates that citizens' fundamental rights over public space receive constitutional protection. Embodied in this mandate, the public trust principle is also one of the fundamental principles of the Constitution, along with separation of powers and the protection of human dignity. From this perspective, the public trust doctrine, in turn, should be understood as a legal tool to enforce the public trust principle.

No legal principle emerges in a vacuum. Legal history has repeatedly shown that the formation and maturation of a legal principle depends on whether it can capture fundamental human values and whether it can develop through cumulative social practice. ${ }^{120}$ The development of the constitutional public trust principle, as I will argue in the following sections, follows the trajectory of how legal principles become cornerstones of our legal system.

\section{The "We the People" Spirit}

First of all, in protecting public space, the public trust principle embodies the "we the people" ethos, an idea that is fundamental to our Constitution. The Preamble of the Constitution states:

WE THE PEOPLE of the United States, in Order to form a more perfect Union, establish Justice, insure domestic Tranquility, provide for the common defence, promote the general Welfare, and secure the Blessings of Liberty to ourselves and our Posterity, do ordain and establish this CONSTITUTION for the United States of America. ${ }^{121}$

U.S. 474, 481 (1988) ("No particularized inquiry into the precise nature of a specific street is necessary; all public streets are held in the public trust and are properly considered traditional public fora.").

120. See, e.g., JoHn FinNis, NATURAL LAW AND NATURAL Rights 245-52 (1980).

121. U.S. CONST. pmbl. 
The Constitution opens with a declaration that we can achieve these goals for all people. The "we the people" spirit lays the foundation for constitutional principles such as separation of powers and the protection of human dignity. These principles do not textually appear in the Constitution, but they are carved into the Constitution as fundamental principles that reflect basic human values and societal pursuits.

The idea of public trust embodies the "we the people" spirit with respect to the inalienable human interest in public space. Both private space and public space form the world in which we live. In contrast to the structure of private space, it is "we" not "me" that share the benefits derived from our involvement in public space and the costs of maintaining and improving public space. This ethos embedded in the public trust principle dates back to Arnold v. Mundy in $1821 .{ }^{122}$ In this case, a riparian landowner claimed private ownership of fishing rights because he claimed to have a grant to the bay. The court relied on "the law of nature, which is the only true foundation of all the social rights," and concluded that the idea of public trust was "nothing but a restoration of common law rights." 123 The court then held that the state cannot "make a direct and absolute grant of the waters of the state, divesting all the citizens of their common right," adding that such a grant "never could be long borne by a free people."124

Later, in Illinois Central, the Supreme Court ruled that it was the need to protect people's rights to "enjoy the navigation of the waters, carry on commerce over them, and have liberty of fishing therein" that triggered the state's obligation to manage these public spaces for the interests of the general public. ${ }^{125}$ In In re Complaint of Steuart Transportation Co., a federal district court stated that "[u]nder the public trust doctrine, the State of Virginia and the United States have the right and the duty to protect and preserve the public's interest in natural wildlife resources. Such right does not derive from ownership of the resources but from a duty owing to the people."126

\section{The Constitutional Practice}

Embedded in the "we the people" spirit, the public trust principle has laid the foundation for some concrete mandates textually adopted or practically used in constitutional law. The practical use of these mandates, especially by

122. Arnold v. Mundy, 6 N.J.L. 1 (N.J. 1821).

123. Id. at $11-12$.

124. Id. at 78 .

125. Ill. Cent. R.R. v. Illinois, 146 U.S. 387, 452 (1892)

126. In re Complaint of Steuart Transp. Co., 495 F. Supp. 38, 40 (E.D. Va. 1980). 
courts, shows the recognition of the importance of the public trust principle in constitutional law.

The public trust principle legitimizes the constitutional rules and doctrines that minimize governmental regulation of citizens' activities in public space. The protection of free speech rights is designed in a manner to foster deregulation of public space by the government or at least to minimize the impact of governmental regulations on the people's activities in public space. The public forum doctrine derived from the First Amendment prohibits unnecessary governmental regulation of speech activities carried out by people in public spaces. Under this doctrine, streets, parks, and sidewalks are designated as traditional public forums open to public discourse. ${ }^{127}$ The government may not close a traditional public forum to speech. To protect free speech rights, the public forum doctrine requires that when the government adopts content-based regulation of speech activities in a public forum, it must show that its action is narrowly tailored to a compelling interest. ${ }^{128}$ If the restriction is content-neutral, ${ }^{129}$ the government action must be "narrowly tailored to serve a significant government interest, and leave open ample alternative channels of communication." 130

Despite the fact that the need for protecting public forums for speech is backed by the First Amendment, the public forum doctrine was first inspired and later supported by the public trust principle. Central to the public forum doctrine is the notion that resources used for speech must be held as public property for the general welfare of the people at large. The rise of the public forum doctrine in the early twentieth century clearly shows the influence of the public trust principle on its development. ${ }^{131}$ For example, in Members of City Council of Los Angeles v. Taxpayers for Vincent, ${ }^{132}$ Section 28.04 of the Los Angeles Municipal Code prohibited the posting of signs on public property. Justice Brennan suggested in his dissenting opinion that public property (such as utility poles in this case) is a "medium of communication [that] is particularly valuable in part because it entails a relatively small expense in reaching a wide audience, allows flexibility in accommodating various formats, typographies, and graphics, and conveys its message in a

127. See Perry Educ. Ass'n v. Perry Local Educators' Ass'n, 460 U.S. 37, 45 (1983) (adding that traditional public forums are "places which by long tradition or by government fiat have been devoted to assembly and debate").

128. Id.

129. Content-neutral regulations include limits on times (e.g., no amplified sound after 10 p.m.), places (e.g., protests only in designated portions of a public park), and manner (e.g., no fireworks) of speech activities.

130. Perry, 460 U.S. at 45.

131. See cases cited supra notes 118-19.

132. Members of City Council of L.A. v. Taxpayers for Vincent, 466 U.S. 789 (1984). 
manner that is easily read and understood by its reader or viewer."133 Therefore, utility poles must be held open as "an important medium of political expression." 134 Justice Brennan's statement clearly shows that the foundation of the public forum doctrine lies in the public trust principle. As long as public property is needed for the public's political communication and discourse, the government must hold that public property in trust for free speech purposes.

Hence, the practice of the public forum doctrine demonstrates the role of the public trust principle in undergirding and legitimizing constitutional measures that protect public space. As we have widely acknowledged that the protection of private property is a basic principle that animated the framing of the constitutional system, so too is the public trust principle. The protection of public property is indispensable to the framing of our constitutional system as well. According to Professor Rose, "there lies outside purely private property and government-controlled 'public property' a distinct class of 'inherently public property' which is fully controlled by neither government nor private agents." 135 The public trust principle comports with the reality of what sustains our human development: both private space/private property and public space/public property play an indispensable role.

Moreover, the rights conferred by the public trust principle are also compatible with the Ninth Amendment, which states that " $[t]$ he enumeration in the Constitution, of certain rights, shall not be construed to deny or disparage others retained by the people." 136 The Ninth Amendment indicates that the Constitution provides a non-exhaustive list of fundamental rights that ought to be recognized as those belonging to citizens. It suggests that interests that are fundamental to human development deserve constitutional protection by the state and federal governments. This has been widely accepted as the Framers' intent in making the Ninth Amendment. For example, Madison emphatically asserted that "the constitution is a bill of powers, the great residuum being the rights of the people." "137 The Supreme Court in Griswold v. Connecticut reaffirmed the need to protect the unenumerated fundamental rights:

[T] he Framers did not intend that the first eight amendments be construed to exhaust the basic and fundamental rights which the

133. Id. at 819 (Brennan, J., dissenting).

134. Id. at 831 .

135. Rose, supra note 92 , at 720 (citation omitted).

136. U.S. CONST. amend. IX.

137. Wayne D. Moore, Constitutional Rights And Powers of the People 121 (1996) (quoting James Madison). 
Constitution guaranteed to the people.... And, the Ninth Amendment, in indicating that not all such liberties are specifically mentioned in the first eight amendments, is surely relevant in showing the existence of other fundamental personal rights, now protected from state, as well as federal, infringement. ${ }^{138}$

As the citizens' interests in public spaces are fundamental to human development, it is essential that their rights in this respect are recognized and protected by constitutional law.

\section{The Movement for Popular Constitutionalism}

It may remain controversial that the Ninth Amendment can accommodate the public trust principle, since it is deemed by some courts and commentators as being intended to protect private rights. ${ }^{139}$ If the Ninth Amendment is not compatible with the public trust principle, then the idea of the living constitution or popular constitutionalism lends strong support to institutionalize it as one of the fundamental constitutional principles. As many scholars have argued, constitutionalism must be envisioned as living beyond the written text of the Constitution and the decisions made by the Supreme Court. "A 'living constitution' is one that evolves, changes over time, and adapts to new circumstances, without being formally amended." ${ }^{140}$ Under this idea, our Constitution adapts to new circumstances in protecting citizens' interests and improving social welfare and order. The canonical text of the Constitution remains unchanged, but the people's will influences its interpretation. The practice includes a variety of statutes, executive

138. Griswold v. Connecticut, 381 U.S. 479, 490, 493 (1965).

139. See, e.g., Troxel v. Granville, 530 U.S. 57, 91 (2000) (Scalia, J., dissenting) ("The Declaration of Independence, however, is not a legal prescription conferring powers upon the courts; and the Constitution's refusal to 'deny or disparage' other rights is far removed from affirming any one of them, and even further removed from authorizing judges to identify what they might be, and to enforce the judges' list against laws duly enacted by the people."); LAURENCE H. TRIBE, AMERICAN CONSTITUTIONAL LAW $776 \mathrm{n} .14$ (2d ed. 1988) (arguing that "[i]t is a common error, but an error nonetheless, to talk of 'ninth amendment rights.' The ninth amendment is not a source of rights as such; it is simply a rule about how to read the Constitution").

140. David A. Strauss, The Living Constitution 1 (2010). 
materials, ${ }^{141}$ the courts' decisions, and citizens' popular will expressed through media and social movements. ${ }^{142}$

The public trust principle comports with the "living constitution" idea. The Framers, after all, did not foresee all the problems that would arise in the constitutional protection of citizens' interests and social justice. In crafting the Constitution, the Framers prioritized the protection of individual liberties against undue government invasion. Although the "we the people" statement in the Preamble of the Constitution leaves considerable room for the Constitution to adapt to protect citizens' interests in public space, no explicit and concrete measures for that purpose were adopted by the Framers when they wrote the Constitution. For example, the Framers did not foresee the massive environmental degradation that humans could cause and the need to adopt measures to protect the environment. ${ }^{143}$ The public trust principle based on the "we the people" spirit makes our Constitution responsive to the changing needs to protect public spaces, in particular our natural environment, in order to sustain and improve our human condition.

Moreover, repeated attempts to use the public trust doctrine to protect the ecology and recreational uses of public spaces suggest that this is itself a Civil Rights Movement, ${ }^{144}$ urging us to radically alter our age-old practices and attitudes. The public trust principle inspired the rise of the environmental movement in the early 1970s and has boosted its momentum and carried it forward. Prompted by the environmental movement, various court decisions and statutes demonstrate the strong momentum in using the public trust principle to protect public space. Therefore, the past decades of judicial practice and numerous statutes enacted to protect public space suggest that these are all the ways in which the "we the people" idea has been accepted and reinforced in the changing world of constitutional practice and theory.

141. See, e.g., William N. Eskridge, JR. \& John Ferejohn, A Republic of Statutes: The NEW AMERICAN CONSTITUTION 12-13 (2010) (proposing that the constitutional democracy advances by means of statutes that supplement or even supplant the written Constitution); Ernest A. Young, The Constitution Outside the Constitution, 117 YALE L.J. 408, 408 (2007) (arguing that "'the Constitution' would include not only the canonical document but also a variety of statues, executive materials, and practices that structure our government").

142. See generally 1 Bruce Ackerman, We The People: Foundations 319 (1991); 2 Bruce ackerman, We The people: Transformations (1998); Larry D. Kramer, The People TheMSElVES: Popular CONSTITUTIONALiSM AND Judicial REVIEW (2004).

143. See KYSAR, supra note 88 , at 229 (noting the desire of certain scholars and activists to constitutionalize environmental principles given the Constitution's current propensity to "restrict the country's ability to address the environmental needs of present and future citizens").

144. Id. at 247-50 (discussing the role of the environmental and Civil Rights Movements in renewing our constitutionalism). 


\section{ENFORCING SOCIAL RESPONSIBILITIES BY PROMOTING THE STEWARDSHIP ETHIC}

In the preceding Part, I discussed how and why the public trust doctrine protects public spaces by conferring upon citizens four categories of public rights. Moreover, I argued that we use the public trust doctrine as a legal tool to carry out the public trust principle as one of the fundamental principles of constitutional law. While granting citizens fundamental rights over public space, the public trust principle underlying the public trust doctrine also impresses social responsibilities upon the stakeholders to protect public spaces.

In this Part, I will show that central to the public trust principle is the recognition and enforcement of social responsibilities that promote the stewardship ethic in protecting public space. Both rights and responsibilities form the foundation of the public trust principle. Moreover, these rights and responsibilities are interdependent on each other. The recognition and imposition of these social responsibilities, as this Part will show, stem from the need to protect the fundamental rights over public space as the collective rights of the citizens. In promoting the stewardship ethic, the enforcement of these social responsibilities, in turn, reinforces the protection of the fundamental rights.

\section{A. Defending the Public's Collective Interest}

\section{Collective Interests in Public Space}

As shown in the preceding Part, based upon the longstanding rights of navigation, commerce, and fishing, aimed at protecting the economic interests of the public, many courts have expanded the scope of public rights to protect the citizens' ecological, cultural, and political interests in public space. These fundamental rights, protected by the public trust principle, are by nature collectively held by members of the public. In this sense, they are not individual rights, but rather collective rights.

Under the public trust principle, everyone shares a stake in the public resources that form public space. Therefore, the realization of the collective rights is indispensable for cultivating human beings as social members and enhancing their interests in communal development. ${ }^{145}$ By contrast,

145. RAZ, supra note 89, at 208 (arguing that collective rights protect "interests of individuals as members of a group in a public good and the [collective] right is a right to that public good because it 
individual rights that protect private property, personal privacy, and so on, are bestowed upon persons primarily for the purpose of promoting their worth and dignity as individual human beings. ${ }^{146}$

The collective-rights approach to the public trust doctrine has afforded the courts with a vantage point to protect the public interest and reinforce the grounds on which they expand the scope of the doctrine. When invoking the public trust doctrine, courts have repeatedly underscored that the doctrine aims to protect the public's rights to access or use the public trust resources, and every member of the public should enjoy such rights on equal terms. In Illinois Central, the Supreme Court drew on the collective-rights approach to establish a new way to protect the public interest in submerged lands by emphatically arguing as follows:

[The title to submerged lands] is a title different in character from that which the State holds in lands intended for sale. It is different from the title which the United States hold in the public lands which are open to preemption and sale. It is a title held in trust for the people of the State that they may enjoy the navigation of the waters, carry on commerce over them, and have liberty of fishing therein freed from the obstruction or interference of private parties. ${ }^{147}$

According to this statement, citizens of the state have collective interests in entering and using the submerged lands in question for the purpose of navigation, commerce, and fishing. In this case, therefore, it is the public's collective right to maintain access to those lands that have primacy over the individual interests of private parties seeking exclusive control of the lands.

\section{The Nature of the Collective Interests}

Judging from the multitude of public trust cases, collective interests over public spaces have three salient attributes. First, they are not divisible

serves their interest as members of the group"). See also Leslie Green, Two Views of Collective Rights, 4 CAN. J.L. \& JURISPRUDENCE 315, 320-24 (1991) (explaining why collective rights should be viewed as rights to collective interests).

146. For Kant, the protection of individual rights is based upon the premise that every human being has autonomy and self-worth, and should be treated as an end rather than means. Thus, it reflects the categorical imperative laid out by Kant: "[A]ll rational beings come under the law that each of them must treat itself and all others never merely as means, but in every case at the same time as ends in themselves." ImMANUAL KANT, GROUNDWORK OF THE METAPHYSICS OF MORALS 92 (Lara Denis ed., Thomas K. Abbott trans., Broadview Press 2005) (1785).

147. Ill. Cent. R.R. v. Illinois, 146 U.S. 387, 452 (1892) (emphasis added). 
in terms of how individuals can share the protected resources. Every member of the public is equally entitled to have access to and make use of the public trust resources that range from navigable waters and submerged lands to public squares and parks. Put differently, public trust resources are by nature an integral whole for members of the public rather than divisible and discrete parts available to be used only by particular persons. ${ }^{148}$

Second, the collective interests protected by the public trust doctrine are not alienable in any circumstances. In Illinois Central, the Supreme Court enunciated a general rule governing allocation of public trust resources by mandating that "control of the State for the purposes of the [public] trust can never be lost." 149 Therefore, the government as the trustee of natural resources can never revoke the public's collective interests or trade them away by transferring the resources to private parties.

The Supreme Court also laid down two exceptions to the general rule of inalienability by prescribing that a government can transfer public trust resources to private parties if and only if (1) they "are used in promoting the interests of the public," or (2) the transfer is made "without any substantial impairment of the public interest." ${ }^{\prime 150}$ Later, in Appleby v. City of New York, ${ }^{151}$ the Supreme Court further interpreted Illinois Central as allowing the grant of full fee to submerged waterways off Manhattan Island. ${ }^{152}$ The Appleby Court read the two exceptions carved out in Illinois Central as having prohibited only the "gross perversion" of the public trust and "abdication of sovereign governmental power," not the alienation per se of the public trust resources. ${ }^{153}$ These two exceptions show that the collective interests in the public trust resources are not alienable even in the circumstances where the government transfers ownership of a resource to a private party. In other words, even if the government changes the ownership status of the resources held under public trust, the public's collective interests remain unchangeable. Given this inalienability, the public can still exercise its rights in certain public trust resources that have come under private control through the conveyance of ownership by the government.

148. See In re Water Use Permit Applications, 9 P.3d 409, 447 (Haw. 2000) (“[T]he public trust doctrine applies to all water resources, unlimited by any surface-ground distinction."); Arnold v. Mundy, 6 N.J.L. 1, 77 (N.J. 1821) (concluding that the coasts of the sea and all navigable rivers in which the tide ebbs and flows, including the water and land under the water, are "common to all the citizens, and that each [citizen] has a right to use them according to his necessities, subject only to the laws which regulate that use").

149. Ill. Cent. R.R., 146 U.S. at 453.

150. Id.

151. Appleby v. City of New York, 271 U.S. 364 (1926).

152. Id. at $402-03$.

153. Id. at 393 . 
Third, the collective interests in public trust resources are exogenous, partly because the realization of those interests hinges on how we deal with the non-human elements of public spaces. The second Part demonstrated that non-human objects, whether made naturally or by men, form an indispensable part of the human condition. ${ }^{154}$ We could not realize our collective interests without preserving or protecting the non-human objects as "members" of public space. The exogenous nature of the collective interests is also reflected in the impact that our use of public spaces has on how future generations will be able to use public space. This is largely because public resources are depletable. If one human generation damages or even exhausts certain public resources, the ability of future generations to meet their own needs by using these resources would be compromised.

\section{B. Social Responsibilities and the Stewardship Ethic}

The public trust principle itself, as shown in the preceding section, embraces an expansive coverage over human collective interests in public space. The collective interests are by nature indivisible, inalienable, and exogenous. Therefore, the fundamental rights that the public trust principle protects are by nature collective rights for the public to enjoy.

The collective-interest attributes of the fundamental rights protected by the public trust principle make the protection of public resources quite intricate. The allocation of these resources has a direct or indirect impact on each member of the public, non-human objects, and future generations. These effects heighten the importance of the ways in which resources in public space must be protected by the stakeholders. The public trust principle accordingly impresses upon those stakeholders strong social responsibilities toward the members of the public, non-human objects in public space, and future generations as well. ${ }^{155}$ By imposing these social responsibilities, the public trust principle promotes the stewardship ethic for protecting public space.

In the following section, I will argue that as a legal tool to enforce the public trust principle, the public trust doctrine relies on social responsibilities that promote the stewardship ethic to protect collective rights over public space. To this end, the doctrine holds the government, the judiciary, and each member of the public as stakeholders responsible for

154. See supra text accompanying notes 71-73.

155. See, e.g., Richard Worrell \& Michael C. Appleby, Stewardship of Natural Resources: Definition, Ethical and Practical Aspects, 12 J. AgRIC. \& ENVTL. ETHICs 263, 263 (1999) ("Stewardship is the responsible use (including conservation) of natural resources in a way that takes full and balanced account of the interests of society, future generations, and other species ....") (citation omitted). 
protecting public spaces. It impresses both positive and negative responsibilities upon the governmental bodies and agencies and the judiciary on the one hand, and upon individuals on the other. As stewards of our public spaces, the government, the judiciary, and individuals as members of the public are supposed to work together under the guidance of the stewardship ethic. The extent to which collective rights can be protected depends on how the public trust doctrine is used to enforce the social responsibilities imposed on the stakeholders of public space.

\section{Government as Steward of Public Space}

Under the public trust framework, the state is the trustee that manages specific natural resources for the benefit of current and future generations as the beneficiaries of this public trust relationship. This is the orthodox model of the public trust doctrine, which emphasizes the central role of the state as the trustee for the preservation of certain natural resources. Under the public trust doctrine, the government has the trustee power to regulate or dispose of natural resources, along with its political responsibility to promote and protect the public's collective interests over those resources.

In the conventional trusteeship model, the doctrine imposes only negative responsibilities upon the government, requiring it not to act in certain ways that run counter to its responsibilities. Accordingly, the doctrine requires that the government shall not convey public trust resources to any private parties unless this would benefit the public interest. For example, in Illinois Central the Supreme Court stated that

The control of the State for the purposes of the trust can never be lost, except as to such parcels as are used in promoting the interests of the public therein, or can be disposed of without any substantial impairment of the public interest in the lands and waters remaining. ${ }^{156}$

However, with the expansion of the scope of the public trust doctrine to tackle environmental protection issues, a new model of the doctrine adds positive responsibilities on the government. I call it the "stewardship model." Under the new model, in addition to its negative responsibilities, the government is required to act affirmatively and proactively to protect the

156. Ill. Cent. R.R. v. Illinois, 146 U.S. 387, 453 (1892). See also Hayes v. Bowman, 91 So. 2d 795,799 (Fla. 1957) ("[The public resource in question] is held in trust for the people for purposes of navigation, fishing, bathing and similar uses. Such title is not held primarily for purposes of sale or conversion into money. Basically it is trust property and should be devoted to the fulfillment of the purposes of the trust, towit [sic]: the service of the people."). 
citizens' collective interests in public spaces. Courts have repeatedly emphasized that the government has "the right and the duty to protect and preserve the public's interest in natural wildlife resources. Such right does not derive from ownership of the resources but from a duty owing to the people." ${ }^{157}$ In this context, the Mono Lake court, for example, articulated the state duty as "an affirmative duty to take the public trust into account in the planning and allocation of water resources, and to protect public trust uses whenever feasible." 158

The stewardship model requires the government to take affirmative measures regarding substantive and procedural values in protecting the public trust resources. First, with regard to the substantive responsibilities, the government is required to act to protect resources from being damaged. Meeting this positive responsibility depends on whether the government acts diligently, prudently, and in good faith. For example, the Louisiana Supreme Court upheld a state project, challenged by oyster fishermen, that flooded oyster beds to help recover the coastline and to enhance wildlife and fisheries. ${ }^{159}$ According to the court, the state's public trust duty to prevent the loss of coastal land validated the project, despite the loss of oyster beds and impact on local fishermen. ${ }^{160}$ Similarly, a Virginia appeals court cited the public trust doctrine in upholding a state agency's order for a riparian landowner to remove unpermitted structures on a pier that interfered with public trust resources. ${ }^{161}$

The government is also required to take measures to stop actions that cause harm to public spaces. For example, acting as trustee of natural resources, the State of Idaho required a company to make a million-dollar effort to remove oil leaked into Idaho's St. Joe River. ${ }^{162}$ Moreover, courts have also used the doctrine to help the government or people to recover damages they sustained due to the pollution of public trust natural resources. ${ }^{163}$

157. In re Complaint of Steuart Transp. Co., 495 F. Supp. 38, 40 (E.D. Va. 1980). See also Nat'1 Audubon Soc'y v. Super. Ct. of Alpine Cnty., 658 P.2d 709, 724 (Cal. 1983) ('[T] he public trust is more than an affirmation of state power to use public property for public purposes. It is an affirmation of the duty of the state to protect the people's common heritage of streams, lakes, marshlands and tidelands, surrendering that right of protection only in rare cases when the abandonment of that right is consistent with the purposes of the trust.").

158. Nat'l Audobon Soc' $y, 658$ P.2d at 728.

159. Avenal v. State, 886 So. $2 d$ 1085, 1088 (La. 2004).

160. Id. at $1101-02$.

161. Evelyn v. Commonwealth Marine Res. Comm'n, 621 S.E.2d 130, 140 (Va. Ct. App. 2005).

162. Zygmunt J.B. Plater et al., EnVironmental LaW and Policy: Nature, LaW, and SOCIETY 1067 (3rd ed. 2004).

163. See, e.g., In re Complaint of Steuart Transp. Co., 495 F. Supp. 38, 40 (E.D. Va. 1980). 
In addition to these substantive responsibilities, the government is also required to follow the due procedure in disclosing relevant information about the management of public trust resources. This disclosure is important because it both informs the public of how the legislative and administrative decisions are adopted, and also gives the public the chance to respond to legislative bodies or administrative agencies if they believe that the decisions were poorly made. Thus, the information disclosure requirement fosters public engagement in the governmental decision-making process concerning public resources. To follow this procedural requirement, Vermont, for example, has issued public guidelines describing the types of "encroachment" projects that are permissible under the public trust doctrine (e.g., water intakes and docks). ${ }^{164}$ The document describes the factors considered when determining whether a project is consistent with public trust values. ${ }^{165}$

\section{Judiciary as Steward of Public Space}

To protect collective interests, the public trust doctrine impresses responsibilities on courts as well. They are required to render judicial decisions to fulfill their responsibilities when either the government or individual parties have taken actions that harm collective human interests in public spaces. In this sense, the judiciary acts as the steward of public space.

The idea of judicial responsibility in this regard differs from the conventional wisdom on the public trust doctrine, which focuses on courts' judicial review power to consider the validity of the government's state action in managing protected resources. The stewardship view goes beyond the courts' power to overturn decisions made by the government and underscores the responsibility of the courts to ensure that collective human interests are safeguarded when state actions are taken to manage public trust resources. The courts, in this scenario, act as stewards defending the collective interest in public trust resources. ${ }^{166}$ For example, with respect to navigable waters and the land underneath them, the Supreme Court in Illinois Central ruled that the government in Illinois must protect the public interest constantly when it makes decisions to allocate public trust

164. See Vt. Agency of Natural Res., Guidance for Agency Act 250 and Section 248 COMMENTS REGARDING RIPARIAN BUFFERS (2005), available at www.anr.state.vt.us/site/html/buff/ BufferGuidanceFINAL-120905.pdf.

165. Id. at 14 .

166. For a similar view, see Peter Manus, To A Candidate in Search of an Environmental Theme: Promote the Public Trust, 19 STAN. ENVTL. L.J. 315, 330 (2000) ("The public trust doctrine is the legal receptacle for the government's long-term duty, as supported by the judicial system, to manage and perpetuate the public enjoyment of natural resources."). 
resources. ${ }^{167}$ Accordingly, if the state action fails the standard of review enunciated in Illinois Central, courts would invalidate the government's decisions regarding allocation of public trust resources and would denounce its "abdication" 168 of its political responsibility to protect the public's collective rights.

The judicial oversight of state action regarding allocation of public trust resources, in effect, empowers the court to overturn decisions made by the government as the representative of the public at large. Antimajoritarian as it is, the public trust doctrine as the basis of this judicial power is legitimized by its role in remedying "the tyranny of the minority" problem that can arise in the democratic decision-making process. ${ }^{169}$ The conundrum inherent in modern democracy, as Carl Schmitt observed, is that political institutions as the venue for deliberating and deciding upon the public good may have been transformed into institutions for powerful interest groups to negotiate and bargain for power and resources. ${ }^{170}$ Those powerful interest groups, routinely formed by large business organizations, are the "minority" parties in the society when compared to the public as the "majority" whose collective interest are supposed to be of central importance in democratic governance. $^{171}$

These "minority" groups are able to drastically reduce the inclusive, democratic deliberation in the legislative and administrative process to the narrow scope of a business meeting concerning the distribution of interests among these interests. Because they wield an unparalleled wealth of resources, these "minority" groups are extremely active in penetrating the structure of democratic deliberation by controlling some or most of the representatives of the public, such as senators and governors. ${ }^{172}$ When these representatives become their "loudspeakers" in the political decision-making process, democratic deliberation degenerates into "an empty formality" and "superfluous decoration" for the public at large. ${ }^{173}$

State action regarding allocation of natural resources is indeed very vulnerable to this "tyranny of the minority" problem. Given that public trust resources have enormous market value, any proprietary control of them would surely generate windfall profits for private parties. Not surprisingly,

167. Ill. Cent. R.R. v. Illinois, 146 U.S. 387, 453 (1892).

168. Id. ("Such abdication is not consistent with the exercise of that trust which requires the government of the State to preserve such waters for the use of the public.").

169. CARl SCHMITT, THE CRISIS OF PARLIAMENTARY DEMOCRACY 6-7 (Ellen Kennedy trans., 1985).

170. Id.

171. Id.

172. Id.

173. Id. at 6 . 
this gives rise to rent-seeking activities ${ }^{174}$ that may be aggressively pursued by private parties with strong economic clout. ${ }^{175}$ By bribing or lobbying government officials in power, these parties take possession of a public trust resource. In contrast, the public at large is always diffuse and unorganized; it is relatively hard to get the public organized to take part in the government's decision-making process about public trust resources. Too often, the public at large is simply unable to wage a struggle to counter the powerful rentseeking activities of large corporations.

Therefore, courts use their judicial review power to fulfill their responsibility to protect the public's collective rights against the tyranny of the minority that may occur if an interest group skews the government's allocation of public resources. As Sax insightfully observed, the public trust doctrine "is a technique by which courts may mend perceived imperfections in the legislative and administrative process." 176 To do so, the doctrine empowers courts to "promote equality of political power for... [the] disorganized and diffused [public as the] majority" whose interest is easily jeopardized by the "self-interested and powerful minorities [who] often have an undue influence on" governmental resource management. ${ }^{177}$

Central to the judicial scrutiny of the government's decisions is an inquiry as to whether the government has fulfilled its role as a steward of public trust resources. Acting as a separate steward of public trust resources, courts investigate whether the government has fulfilled its responsibilities for serving the public interest. To examine the substantive value issues, courts have relied on the standard of review used in Illinois Central to determine whether the government has fulfilled its political responsibilities. Guided by the public purpose principle stated in Illinois Central, ${ }^{178}$ courts have defined how to determine whether the government's decisions in conveying ownership serve the public interest. For example, in Wisconsin $v$.

174. Rent-seeking is the expenditure of resources in an effort to capture these supra-normal returns. Lobbying for special legislative privileges is a classic example. See generally James M. Buchanan, Rent Seeking and Profit Seeking, in TOWARD A THEORY OF THE RENT-SEEKING SocieTy 3, 3 (James M. Buchanan et al. eds., 1980).

175. See Ragnar Torvik, Natural Resources, Rent Seeking and Welfare, 67 J. DeV. ECON. 455 (2002) (outlining the problem of rent-seeking behavior in natural resources management).

176. Sax, supra note 8, at 509 .

177. Id. at 560; Matthew Park, The Public Trust Doctrine: Ensuring the Public's Natural Right of (Perpetual) Access to Common Resources 5 (Mar. 10, 2010) (unpublished LL.M. thesis, University of Victoria) (on file with UVicDSpace, University of Victoria), available at https://dspace.library.uvic.ca:8443 //handle.net/1828/2344 (click on "Park M. LLM.pdf" at the bottom of the page) ("By prescribing a principled approach to environmental decision making, the public trust doctrine serves as a democratizing force by preventing the monopolizing of trust resources into private and unaccountable hands.").

178. See supra text accompanying notes $28-31$ and $155-57$. 
Public Service Commission, ${ }^{179}$ a case involving a challenge to the legislature's grant of a lakebed to the City of Madison, the court introduced a five-factor standard that should be met:

1. Public bodies will control the use of the area. 2. The area will be devoted to public purposes and open to the public. 3. The diminution of lake area will be very small when compared to the whole of [the lake]. 4. No one of the public uses of the lake as a lake will be destroyed or greatly impaired. 5 . The disappointment of those members of the public who may desire to boat, fish, or swim in the area to be filled is negligible when compared with the greater convenience to be afforded those members of the public who use the city park. ${ }^{180}$

Regarding procedural issues, courts have examined whether the government's decision-making has adequately considered the interests of major stakeholders through open and fair procedures. ${ }^{181}$ To this end, the court could consider whether decisions are made with sufficient public notice so as to keep the public reasonably informed and give the public sufficient time to prepare and organize to respond. ${ }^{182}$ In particular, the doctrine requires that the legislative body must take measures to have representatives of the public closely involved in the decision-making process. ${ }^{183}$ For example, the legislative body may invite civil society organizations such as environmental NGOs to present their concerns about the impact of any proposed new laws on the public interest in access to, and use of, public trust resources. Courts can strike down any law enacted without participation by the representatives of the public, or order the legislature to revise the law by actively having those representatives engaged in the process.

Besides their role as stewards against wrongdoings committed by the government, courts have also acted as stewards for the public to prevent private parties from harming the public interest. What courts do in this domain definitely goes beyond their role as the judicial check on state

179. Wisconsin v. Public Serv. Comm'n, 81 N.W.2d 71, 71 (Wis. 1957).

180. Id. at 73-74.

181. See Kay Lehman Schlozman \& John T. TiERneY, ORganized InTERESTS AND AMERiCAN DEMOCRACY 314-15 (1986) (noting that empirical research shows that lobbying is most effective when the interest group's goals are narrow and the legislation involves issues of "low-visibility" from the general public's perspective).

182. See, e.g., Robert Cox, EnVironmental Communication And the Public Sphere 84 (2nd ed. 2010) (discussing the importance of protecting the public's right to access information and to comment on environmental matters).

183. Id. 
action, as contended by public trust protagonists led by Professor Sax. ${ }^{184}$ Sometimes the harm caused by private parties to public spaces can be too serious to wait for the time-consuming legislative process to respond or for the inactive or even corrupted executive to take necessary action. Courts may fulfill their responsibilities by issuing injunctions to swiftly order a halt to damaging private actions. The judicial actions can also provide remedies to affected members of the public to compensate for the damage they have suffered.

For example, in United States v. Snook, the Seventh Circuit held Snook criminally liable for knowingly reporting to the government materially wrong information about the quality of wastewater he was entrusted to monitor. ${ }^{185}$ The court argued that:

The Clean Water Act is public-welfare legislation and the victims of violations are the public.... [F]or over three years [the] wastewater had numerous violations that went undetected because Snook, in his unique position as Environmental Manager, did not report them. Moreover, unlike other self-reporting situations (taxpayers, for example), the regulations here apply to matters that directly and significantly affect the public's health and safety. ${ }^{186}$

Given Snook's blatant violation of the public trust and the magnitude of the environmental degradation due to his violation, the court upheld a sentencing increase. ${ }^{187}$ Judicial decisions of this type exemplify the important role of courts in preventing and stopping damaging private actions. ${ }^{188}$

\section{Individuals as Stewards of Public Space}

The public trust doctrine also imposes social responsibilities on individuals as members of the public. This is of primary importance because approximately one-third of property claimed by the states to be public trust

184. See, e.g., Sax, supra note 63.

185. United States v. Snook, 366 F.3d 439, 446 (7th Cir. 2004).

186. Id. at 445-46.

187. Id. at 446 .

188. See, e.g., United States v. Perez, 366 F.3d 1178, 1180 (11th Cir. 2004) (upholding sentence enhancement for discharging pollutants into wetlands of the United States); United States v. GonzalezAlvarez, 277 F.3d 73, 81-82 (1st Cir. 2002) (holding that abuse-of-trust increase applied to dairy farmer for not complying with regulations); United States v. White, 270 F.3d 356, 372-73 (6th Cir. 2001) (same in context of employee at water-treatment plant); United States v. Turner, 102 F.3d 1350, 1360 (4th Cir. 1996) (same in context of owners and operators of coal mine). But see United States v. Technic Servs., Inc., 314 F.3d 1031, 1049 (2002) (refusing to apply an abuse-of-trust increase to an asbestos remediation private contractor). 
property is in private rather than public hands. ${ }^{189}$ Social responsibilities constrain private action under circumstances in which public needs in privately-controlled resources must be accommodated. These responsibilities have been legally enforced by the public trust doctrine against individual property owners.

Courts have invoked the public trust doctrine to order the opening of private property to accommodate public access and use. In this circumstance, courts routinely ascertain that public access to, or use of, the relevant private property is the necessary condition by which the public can meaningfully exercise their collective rights over trust resources. For example, the New Jersey Supreme Court found that the "[e]xercise of the public's right to swim and bathe below the mean high water mark may depend upon a right to pass across the upland beach. Without some means of access the public right to use the foreshore would be meaningless. ${ }^{, 190}$ Hence, the court ruled that the public must be afforded access through privately-owned upland areas as necessary for them to exercise their public trust right to bathe or swim in the foreshore areas.

The public trust doctrine also requires that private parties who obtain ownership of public trust resources from the government must accommodate public access to, and use of, those resources under their control. The private ownership conferred by the government is seen as a bifurcated title. The party has acquired private ownership over the resource concerned; this title, under the common law, is recognized as jus privatum. But the title is subject to the public's collective rights over the resources concerned; the common law regards these collective rights over public trust resources as jus publicum protected by the state. ${ }^{191}$ The bifurcated title shows that while the government can alienate public trust resources on appropriate occasions, it cannot give up its responsibility to protect public interests in those resources. Thus the public can still exercise their rights over privately controlled resources obtained from the government's privatization schemes. ${ }^{192}$ For example, regarding littoral

189. Smith \& Sweeney, supra note 17, at 332.

190. Matthews v. Bay Head Imp. Ass'n, 471 A.2d 355, 364 (N.J. 1984). Moreover, in an earlier case the court also stated that "a modern court must take the view that the public trust doctrine dictates that the beach and the ocean waters must be open to all on equal terms and without preference." Neptune City v. Avon-by-the-Sea, 294 A.2d 47, 54 (N.J. 1972).

191. See, e.g., Appleby v. City of New York, 271 U.S. 364, 399 (1926) (ruling that the ownership of submerged lands carrying both the jus publicum and the jus privatum belonged to a private party); Shively v. Bowlby, 152 U.S. 1, 11 (1894) (holding that "the title, jus privatum, in [tidelands] . . belongs to the King as the sovereign; and the dominion thereof, jus publicum, is vested in him, as the representative of the nation and for the public benefit"); Glass v. Goeckel, 703 N.W.2d 58, 65 (Mich. 2005) ("Jus publicum refers to public rights in navigable waters and the land covered by those waters; jus privatum, in contrast, refers to private property rights held subject to the public trust.").

192. See, e.g., Glass, 703 N.W.2d at 65 ("At common law, our courts articulated a distinction 
rights granted by the government, courts have repeatedly held that "although the state retains the authority to convey lakefront property to private parties, it necessarily conveys such property subject to the public trust." 193

By requiring public accommodations on private property, the public trust doctrine imposes upon property owners both negative and positive social responsibilities. For the negative responsibility, the doctrine requires that private property owners not use their property in a manner that prevents the public from exercising their collective rights under the public trust doctrine. In fact, the imposition of negative responsibilities reflects a long-recognized principle that "all property ... is held under the implied obligation that the owner's use of it shall not be injurious to the community" 194 or other individuals. ${ }^{195}$ For instance, in Orion Corp. v. State, Orion Corporation, the owner of 5,600 acres of Padilla Bay tidelands in Washington attempted to dredge and fill Padilla Bay to create a residential community. ${ }^{196}$ The court held that Orion's purchase of the tidelands was subject to the public trust and must accommodate public interests, the jus publicum interest of all the citizens. ${ }^{197}$ Hence, Orion Corporation had a responsibility not to dredge and fill the tidelands so as to "substantially impair the public rights of navigation and fishing, as well as incidental rights and purposes [for boating, swimming, or water skiing]." ${ }^{, 198}$ Similarly, filling of tidal waters was also invalidated in Palazzolo v. State ${ }^{199}$ based on the public trust doctrine. Courts have also held that private owners have a responsibility not to erect fences on their properties that would prevent the public from exercising the right to walk on the lake shores below the high water mark ${ }^{200}$ or to use the lake waters. ${ }^{201}$

\footnotetext{
between jus privatum and jus publicum to capture this principle: the alienation of littoral property to private parties leaves intact public rights in the lake and its submerged land."); Caminiti v. Boyle, 732 P.2d 989, 994 (Wash. 1987) ("The state can no more convey or give away this jus publicum interest than it can 'abdicate its police powers in the administration of government and the preservation of the peace."”) (citing Ill. Cent. R.R. v. Illinois, 146 U.S. 387, 453 (1892)).

193. Glass, 703 N.W.2d at 65.

194. Mugler v. Kansas, 123 U.S. 623, 665 (1887) (citations omitted).

195. See, e.g., Pennsylvania Coal Co. v. Mahon, 260 U.S. 393, 417 (1922) (Brandeis, J., dissenting) (contending that "the right of the owner to use his land is not absolute. He may not so use it as to create a public nuisance; and uses, once harmless, may, owing to changed conditions, seriously threaten the public welfare.").

196. Orion Corp. v. State, 747 P.2d 1062, 1065 (Wash. 1987) (en banc).

197. Id.

198. Id. at 1073. In an earlier case, the court required littoral property owners to remove fills that prevented submergence of their shoreline and thus impeded their neighbors' access to the adjoining lake. Wilbour v. Gallagher, 462 P.2d 232 (Wash. 1969) (en banc).

199. Palazzolo v. State, No. 88-0297, 2005 R.I. Super. LEXIS 108, at *29 (R.I. Super. Ct., 2005).

200. See, e.g., Glass, 703 N.W.2d at 66 (explaining that "the public trust extends to all land below the ordinary high water mark").

201. See, e.g., Lincoln v. Davis, 19 N.W. 103, 111 (Mich. 1884) ("There can be no doubt of the right of the state to forbid any erections within such parts of the water as are strictly navigable, and to regulate the distance beyond which no private erections can be maintained.").
} 
With respect to positive responsibilities, private property owners are required by the public trust doctrine to carry out certain tasks to facilitate the public's exercise of their collective rights. For instance, given that access through dry sand areas is indispensable for the public to make recreational use of the foreshore areas, the New Jersey Supreme Court ordered that private property owners are required to afford the public not only "reasonable access to the foreshore" but also "a suitable area for recreation on the dry sand."202

\section{RESPONDING TO CRITICISMS OF THE PUBLIC TRUST DOCTRINE}

In the Part that follows, I will consider how the new theoretical foundation of the public trust doctrine and the new mode of the doctrine proposed in this Article can contribute to responses to attacks on the doctrine. As demonstrated in Part I, critics have attacked the public trust doctrine by focusing on its emphasis on judicial intervention in the management of public resources. They criticized Sax and his followers for using the doctrine to promote a judiciary-based, top-to-bottom model for regulating public spaces, which results in giving too much power to courts.

In contrast, the social-political theory I propose in this Article shows that the public trust doctrine is by no means a legal tool that simply relies on courts to protect public resources. Instead, the doctrine is founded on the public trust principle, aimed at affording constitutional protection of fundamental rights over public space. Based on this social-political foundation, the public trust doctrine embodies a new mode of application that invokes social responsibilities in order to promote a stewardship ethic of protecting public space.

Therefore, the earlier attacks on the public trust doctrine would falter, given that the doctrine is in fact a dynamic and comprehensive legal tool that does not center on the top-down role of the judiciary. Rather, the doctrine embodies both top-to-bottom and bottom-to-top mechanisms in protecting public space. On the one hand, the practice of the doctrine closely involves the government and judiciary as stewards of the public trust; the decisions passed down by them are of pivotal importance in protecting public spaces. On the other hand, individuals as members of the public also play an important part. Exercising the collective rights bestowed upon them, members of the public also act as stewards of public spaces and can press both the government and judiciary to protect public space in a manner conducive to the public interest.

Based on this central response to the attacks on the public trust doctrine, I

202. Raleigh Ave. Beach Ass'n v. Atlantis Beach Club, Inc., 879 A.2d 112, 121 (N.J. 2005) (citing Matthews v. Bay Head Imp. Ass'n, 471 A.2d 355 (N.J. 1984)). 
will examine more problems in these attacks in the following three sections and discuss how the social-political theory I propose can address these problems. I will also explain more about the merits of the public trust doctrine compared with the alternatives proposed by the critics.

\section{A. Concern about Judicial Incompetence}

As shown in Part I, some critics faulted the proponents of the public trust doctrine for their ignorance of evidence that legislative bodies and administrative agencies have considerable expertise to deal with increasingly complex environmental problems. ${ }^{203}$ In their view, the legislative bodies and administrative agencies are the proper institutions to develop a comprehensive regulatory regime for environmental protection, and not the courts, which lack adequate expertise to address a host of environmental problems.

It is true that the institutions in the government (such as the Environmental Protection Agency) can acquire the expertise to respond to ever-changing and increasingly complex environmental problems. But the harsh reality is that our natural environment has suffered significant deterioration in the past few decades despite the government's increasing experience in regulating environmental pollution. ${ }^{204}$ This massive failure has occurred for a variety of reasons, ${ }^{205}$ with the government's vulnerability to lobbying efforts by the polluting industries probably the most important factor. $^{206}$

The social-political theory I propose in this Article accommodates the need to tap into the government's expertise in dealing with environmental problems, since the government is deemed to be a steward of public spaces. More importantly, the public trust principle may help the government to legitimize the measures it adopts to protect public space at large, given that the government has a responsibility to protect fundamental rights over

203. See,e.g., supra note 57 and accompanying text.

204. See James Gustave Speth, Red Sky at Morning: America and the Crisis of the GLOBAL ENVIRONMENT, at $\mathrm{x}$-xi (2004) (discussing the massive scale of the environmental problems facing the world).

205. See, e.g., Jason J. Czarnezki \& Mark L. Thomsen, Advancing the Rebirth of Environmental Common Law, 34 B.C. ENVTL. AFF. L. REv. 1, 2 (2007) (pointing out that "national standards may not be suitable for greenhouse gases, and federal agencies sometimes lack the resources to effectively perform restoration activities or federal standards are inadequate to restore affected resources to a state's more stringent standard").

206. See, e.g., Dan Bacher, How Oil Lobbyists Are Writing California's Environmental Laws, COUNTER PUNCH (July 16-18, 2010), http://www.counterpunch.org/bacher07162010.html; Jim Walker, Cruise Industry Spent \$400,000 Last Quarter Lobbying Against Safety \& Environmental Regulations, CRUISE LAW NEWS (March 8, 2010), http://www.cruiselawnews.com/2010/03/articles/lobbying/cruiseindustry-spent-400000-last-quarter-lobbying-against-safety-environmental-regulations/. 
public space. In Part II, I demonstrated that our Constitution lacks any direct and explicit provisions for protecting the citizens' fundamental rights over public space, with the result that the government at the federal level may not have adequate power under the Constitution to take measures to protect public spaces. For example, the Supreme Court has struck down federal statutes that regulated environmental pollution or bearing of guns in school areas (which are public spaces) on the basis that the federal government does not have the authority to enact these statutes. ${ }^{207}$

Apart from accommodating and legitimizing the government's regulatory measures, the social-political theory I propose would generate a more comprehensive way to protect public spaces. This is because it combines the agenda of protecting citizens' fundamental rights over public space with the enforcement of social responsibilities centered on protecting public spaces. In doing so, it seeks to engage and mobilize not only the government and judiciary, but also individuals as members of the public, to become stakeholders in protecting public space.

Under the social-political theory, the synergy between fundamental rights and social responsibilities is generated by applying both the bottomto-top and top-to-bottom modes of the public trust doctrine. First, the bottom-to-top mode mobilizes grassroots power to protect a variety of public resources, entitling every citizen standing to sue wrongdoers. Meanwhile, the top-to-bottom mode of the public trust doctrine mandates the government to take a proactive approach in managing public resources.

Motivated by the environmental movement, the expansive application of the public trust doctrine has granted open standing to members of the public to challenge the potentially inappropriate use of public resources by the government or private parties. In Paepcke v. Public Building Commission, the Illinois Supreme Court ruled that citizens had standing as beneficiaries of public trust resources to challenge the diverting of public park space for the construction of school buildings. ${ }^{208}$ Later, in the landmark National Audubon Society decision, the California Supreme Court sweepingly reaffirmed that "any member of the general public ... has standing to raise a claim of harm to the public trust." 209

The collective rights approach bestows upon any member of the public the standing to sue because it recognizes that each member of the public enjoys an indivisible and inalienable interest in the resources held under public trust. If the government or any private parties cause harm to the

207. See, e.g., United States v. Lopez, 514 U.S. 549, 567 (1995).

208. Paepcke v. Public Bldg. Comm'n, 263 N.E.2d 11, 18 (Ill. 1970). omitted).

209. Nat'l Audubon Soc. v. Super. Ct. of Alpine Cnty, 658 P.2d 709, 716 n.11 (Cal. 1983) (citation 
public trust resources, the wrongdoing will cause direct or indirect harm not only to one individual citizen but also to all the members of the public. ${ }^{210}$ Thus, the court in Paepcke noted that "[i]f the 'public trust' doctrine is to have any meaning or vitality at all, the members of the public, at least taxpayers who are the beneficiaries of that trust, must have the right and standing to enforce it." 211 It not only entitles citizens to sue against the wrongdoings of the government or any private parties, but also empowers them to seek remedies in court when the law is silent or the government is inactive. The court also observed that "[t]o tell [people] that they must wait upon governmental action is often an effectual denial of the right for all time. ${ }^{212}$ In a case involving a shooting range that was disturbing residential neighbors, the court found a MERA violation for impairment of "quietude" and enjoined the range's operation even though there were no local or state noise standards in place. $^{213}$ Indeed, state statutory law prohibited state agencies from even enacting such standards. ${ }^{214}$

Therefore, the public trust doctrine is a gap-filling tool that makes our system actively responsive to changing circumstances and social needs. Under this public trust framework, any members of the public, both in theory and practice, can become watchdogs of how the trust resources are used. With the active involvement of the general public, it mobilizes the grassroots power to closely monitor how the public trust resources are used.

The collective rights approach also encourages the government to become proactive in managing public trust resources. This is partly the result of the standing entitlement bestowed by the collective rights upon the members of the public; the government is put under the pressure that it will be sued by its citizens if it mismanages public trust resources. In response, the government is more likely to take measures to manage the resources in an appropriate way.

Informed by the collective rights approach, the government is also more likely to institute a decision-making process that comprehensively examines the impact of its decisions on the collective interests of the public. In certain circumstances, the public includes future generations, and we cannot harm or even deplete the resources that they will need. Armed with this vision, the

210. Ctr. for Biological Diversity, Inc. v. FPL Group, Inc., 83 Cal. Rptr. 3d 588, 601 (Cal. Ct. App. 2008) ("The interests encompassed by the public trust undoubtedly are protected by public agencies acting pursuant to their police power and explicit statutory authorization. Nonetheless, the public retains the right to bring actions to enforce the trust when the public agencies fail to discharge their duties.").

211. Paepcke, 263 N.E.2d at 18.

212. Id.

213. Citizens for a Safe Grant v. Lone Oak Sportsmen's Club, Inc., 624 N.W.2d 796, 806, 808 (Minn. Ct. App. 2001).

214. Id. 
government will surely behave more cautiously because its decisions always have a serious and comprehensive impact on the public at large. After all, if the government is repeatedly reminded that taking proactive measures is a mandate under the public trust doctrine, governmental decisions are more likely to be in the public interest.

\section{B. Concern About the Danger of Judicial Supremacy}

Some critics, as shown in Part I, ${ }^{215}$ also worry about the role of the public trust doctrine in subverting the democratic order by giving too much power to the courts. In their view, an active and expansive application of the public trust doctrine will inevitably lead to judicial supremacy by letting the courts have the last say on every decision about resource management. In opposing this alleged threat to democracy, critics argue that courts do not have this kind of power or the expertise to review the decisions of the government.

Using the public trust doctrine, I proposed in the preceding two Parts that there is a new way to justify judicial review. The courts derive this power from their responsibility as stewards of public spaces, which requires them to defend the citizens' collective rights.

The practice of the public trust doctrine clearly demonstrates that there are ecological, economic, and cultural manipulations in the allocation and management of public resources. When there are manipulative actions that cause harm to public space, courts must decide when suits are brought to them. It is their responsibility to protect public spaces that makes it necessary for them to exercise the judicial review power. In this capacity, the courts act as the stewards of citizens' fundamental rights.

Courts have indeed played an indispensable role in breaking barriers to justice and freedom in times of crisis. ${ }^{216}$ A court in England invalidated a monopoly in trade granted by Queen Elizabeth I dating back to the late sixteenth century. ${ }^{217}$ In the new millennium, it was the Supreme Court that liberated homosexuals from the homophobia inherent in anti-sodomy laws ${ }^{218}$ and denounced the deprivation of Guantánamo detainees' constitutional right

215. See supra notes50-51 and accompanying text.

216. For general positions in favor of judicial review based on the unique status of courts in our constitutional system, see, e.g., RONALD DWORKIN, FREEDOM's LAW (1996) (discussing the weakness of the majoritarian premise); Yuval Eylon \& Alon Harel, The Right to Judicial Review, 92 VA. L. REV. 991, 991 (2006) (arguing that the right to a hearing forms the basis for judicial review); Richard H. Fallon, Jr., The Core of an Uneasy Case for Judicial Review, 121 HARV. L. REV. 1693, 1695 (2008) (arguing that courts should protect fundamental rights and have the power to overturn legislation that violates these rights).

217. The Case of Monopolies, (1601) 77 Eng. Rep. 1260 (K.B.); 11 Co. Rep. 84 b.

218. Lawrence v. Texas, 539 U.S. 558, 574 (2003). 
to challenge their detention in American courts. ${ }^{219}$ These crises have resonance with Rousseau's warning: "Nothing is more dangerous than the influence of private interests on public affairs, and abuse of the laws by the Government is a lesser evil than the corruption of the Lawgiver. ..."220 Indeed, all of these crises, together with the environmental crisis in our natural and cultural ecosystems, clearly reveal the potential manipulative power wielded by interest groups and legislatures. When courts can use the judicial review power to fulfill their responsibilities to protect private rights that are recognized as fundamental rights under the Constitution, the same must apply to the protection of fundamental rights over public resources and public space. After all, the protection of both private rights and public rights, as demonstrated in Part II, ${ }^{221}$ are equally important for human development. We cannot ignore the role of courts in defending public rights while putting them to work in the protection of private rights.

The recent litigation about Burholme Park in downtown Philadelphia demonstrates how courts can exercise the judicial review power to fulfill their responsibilities under the public trust doctrine. ${ }^{222}$ In this case, the Fox Chase Cancer Center, one of the nation's top hospitals devoted to cancer treatment, research, and prevention, entered into a lease agreement with the City of Philadelphia to expand its campus into Burholme Park, which stands next to the Center and is used by people for recreation. ${ }^{223}$ The core question was whether the court should uphold or overturn the government's decision to lease the parkland for the economic development of the city, as the Fox Center's expansion into the park would create more jobs and provide the city with funds. ${ }^{224}$

In this case, the court fulfilled its judicial responsibilities under the public trust doctrine and protected the recreational uses of the park by the public. It ruled that "so long as a community or neighborhood actively uses dedicated park land, the City is required to hold such land in trust for their use, is legally estopped from divesting such land and is required to maintain these open spaces as public parks." 225

219. Boumediene v. Bush, 128 S. Ct. 2229, 2275 (2008).

220. Jean-Jacques Rousseau, The Social Contract and Other Later Political Writings 91 (Victor Gourevitch ed., 1997).

221. See supra notes $68-77$ and accompanying text.

222. In re Estate of Ryerss, 2008 Phila. Ct. Com. Pl. LEXIS 287 (Ct. Com. Pl. 2008), aff'd, 987 A.2d 1231 (Pa. Commw. Ct. 2009), available at http://www.publicvoiceforpublicspace.org/images/ stories/ 20081209.

223. Id. at *1-2.

224. Id. at *1.

225. Id. at *106. 
Any institutional design, to a larger or lesser degree, carries defects, and the public trust doctrine and the court's role in defending the public interest are no exceptions. In order to avoid judicial supremacy, courts in exercising their judicial review power should show deference to the expertise of the legislative bodies and administrative agencies.

\section{Concern About the Tragedy of the Commons}

Some opponents of the public trust doctrine, as shown in Part I, ${ }^{226}$ also criticized the doctrine for triggering takings of private property without fair compensation. But they seem to have ignored the social responsibilities that private property owners must assume in order to protect public space.

As shown in Part III, ${ }^{227}$ individuals, as well as the government and judiciary, act as stewards of public space. Therefore, the public trust doctrine bestows upon individuals social responsibilities to protect public spaces as well. When it comes to cases that deal with takings of property, the inquiry should not just focus on the extent to which property owners enjoy exclusive rights; their social responsibilities also need to be fully taken into account.

For example, McQueen v. South Carolina Coastal Council, ${ }^{228}$ a decision frequently cited by opponents in their attacks on the public trust doctrine ${ }^{229}$ upheld the South Carolina Coastal Council's restriction imposed on the use of property that includes tidelands. ${ }^{230}$ The decision was based on the fact that Mr. McQueen, the property owner concerned, had responsibilities to contribute to the preservation of the tidelands in his parcels of property. The public trust doctrine used by court to rule against the takings claim imposes social responsibilities on property owners, and the court accordingly held that the doctrine places "a restriction on McQueen's property rights inherent in the ownership of property bordering tidal water." 231

The opponents of the public trust doctrine turn a blind eye to the social responsibilities that ought to be imposed on property owners, largely

226. See supra notes 52-56 and accompanying text.

227. See supra notes $162-176$ and accompanying text.

228. McQueen v. S. C. Coastal Council, 580 S.E.2d 116, 120 (S.C. 2003).

229. See, e.g., Simmons, supra note 19, at 15-17 (arguing that the public trust doctrine-based decision in McQueen undermines private property and empowers government).

230. Id.

231. McQueen, 580 S.E.2d at 120. In addition, the Court stated that "[s]ignificantly, under South Carolina law, wetlands created by the encroachment of navigable tidal water belong to the State. ... The tidelands included on McQueen's lots are public trust property subject to the control of the State. McQueen's ownership rights do not include the right to backfill or place bulkheads on public trust land and the State need not compensate him for the denial of permits to do what he cannot otherwise do." Id.. 
because they believe that the right to exclude is the essence of private property protection. ${ }^{232}$ Being highly concerned about the danger posed by the public trust doctrine to private property, the critics see privatization of resources as a panacea for addressing a host of social problems. To them, promoting privatization and strengthening private property protection are central to maintaining a free and healthy society. The public trust doctrine, however, stands in the way to prevent massive privatization of public resources.

The rhetoric of the tragedy of the commons lends the strongest support to these critics' proposals. It teaches that privatization is one solution for the overuse or depletion of natural resources. ${ }^{233}$ Moreover, given the heightened difficulty in reaching agreement due to the increased transaction costs when the number of parties increases, the theory of collective action further adds to the rhetorical basis for preferring privatization of natural resources. ${ }^{234}$ The economic justification for privatizing natural resources thus centers on the need to allocate exclusive control over resources to those who can make optimal use of them. It further highlights the role of the free market in bringing about maximization of wealth for personal and social development. ${ }^{235}$

Yet privatization begs the question of why certain natural resources, such as the Mississippi River and Central Park in New York City, ought to be held in public trust and not subject to private ownership. The rationale against expansive privatization of natural resources, by and large, stems from the fact that the free market, despite its liberty-promoting function, results in coercion by creating monopolization of resources. In a modern society, it is inevitable for every person to get involved in the trade that takes place in the marketplace. While every person has an equal nominal status as a trading participant in the marketplace, the type or amount of resources that they control in fact differs from one person to another. Therefore, the bargaining power they have for negotiating deals in the

232. See, e.g., Simmons, supra note 19 , at 21 (" $[\mathrm{I}] \mathrm{f}$ the ability to exclude is taken away by making the resource available to anyone who wants to use it, the incentive to improve the resource is diminished.").

233. See Garrett Hardin, The Tragedy of the Commons, 162 SCI. 1243, 1247 (1968). Aristotle advanced a similar idea. For example, he stated: "that which is common to the greatest number has the least care bestowed upon it. Every one thinks chiefly of his own, hardly at all of the common interest ... [for] everybody is more inclined to neglect the duty which he expects another to fulfill." ARISTOTLE, Politics 1261b (T. A. Sinclair trans., Trevor Saunders rev. trans., Penguin Books rev. ed. 1981, 1982).

234. See generally MANCUR OLSON, THE LOGIC OF COLLECTIVE ACTION 125-28 (1971) (arguing that large-group organization is ineffective where the benefits are collective because of free riding).

235. See, e.g., Richard A. POSNer, ECONOMic ANAlysis OF LAW 32-34 (6th ed. 2003); Harold Demsetz, Towards a Theory of Property Rights, 57 AM. ECON. Rev. 347, 356 (1967). 
marketplace always varies from person to person, and people with stronger bargaining power can coerce others into following their commands. ${ }^{236}$

From the bargaining-power perspective, an expansive privatization of natural resources would bring out the problem that the private owner could coerce members of the public. For example, by relying on the right to exclude, a private owner may prevent the public from exercising their public trust rights, such as walking across the private beach for fishing, bathing, or swimming in the sea, and walking along privately-owned lake shores to relax. ${ }^{237}$ The public trust doctrine has been invoked by courts to stop the use of coercive power in this kind of case. For example, the New Jersey Supreme Court ruled that the public is entitled to have unimpeded access to, and make reasonable use of, privately-owned dry sand beaches to use the foreshore areas for recreational purposes. ${ }^{238}$

In addition, if certain natural resources that are social necessities fall into private control, property owners may charge access and use fees that most members of the public cannot afford. Recognizing the grave harm that may be caused by monopolization of certain natural resources, courts have repeatedly used the public trust doctrine to prevent navigable waters and the lands underneath them from being held under proprietary control. These resources inherently have public trust status because they are indispensable for commercial activities ${ }^{239}$ as the "highways of commerce." 240 Therefore, the public trust doctrine aimed at keeping navigable waters open for all commercial activities, as the court concluded, "is founded upon the necessity of preserving to the public the use of navigable waters from private interruption and encroachment." 241

\section{CONCLUSION}

Based on the new social-political theory that I propose in this Article, the public trust doctrine resonates strongly with Justice Holmes' view that law is " $[\mathrm{t}]$ he felt necessities of the time." ${ }^{242}$ Indeed, the doctrine is by nature to "be molded and extended to meet changing conditions and needs of the

236. See Robert L. Hale, Coercion and Distribution in a Supposedly Non-Coercive State, 38 PoL. SCI. Q. 470 (1923).

237. Town of Orange v. Resnick, 109 A. 864, 865 (Conn. 1920) (listing as public rights "fishing, boating, hunting, bathing, taking shellfish, gathering seaweed, cutting sedge, and ... passing and repassing").

238. Matthews v. Bay Head Improvement Ass'n, 471 A.2d 355, 364 (N.J. 1988)

239. See Rose, supra note 92, at 753-54 (explaining the function of waterways).

240. Packer v. Bird, 137 U.S. 661, 667 (1891). See also Shively v. Bowlby, 152 U.S. 1, 49 (1894) ("[T] he navigable waters and the soils under them . . . shall be and remain public highways ....").

241. Ill. Cent. R.R. v. Illinois, 146 U.S. 387, 436 (1892). See also Gibbons v. Ogden, 22 U.S. 1, 240 (1824) (invalidated exclusive privilege to navigate New York waters with steam vessels).

242. Oliver Wendell Holmes, The Common LAW 1 (ABA 2009) (1881). 
public it was created to benefit." ${ }^{243}$ I have argued that with the expansive use of the public trust doctrine on various fronts, we have transformed the doctrine into what I call the "public trust principle" that protects the citizens' fundamental rights over public space. I have further demonstrated that these fundamental rights are by nature collective rights that are bestowed upon individuals as members of the public. To enforce the public trust principle, the public trust doctrine is a legal tool that promotes the stewardship ethic of protecting public space, with the government, the judiciary, and individuals as members of the public all being such stewards. Based on these arguments, I have also shown that this theory of the public trust doctrine is capable of yielding effective responses to the criticisms that have been leveled against the conventional ideas of the doctrine.

Given the paramount importance of public spaces in human development, we must strive to keep innovating our legal system with renewed vision and momentum. For the public trust doctrine, both history and contemporary reality have shown its great potential for defending public spaces. Now it remains up to us to capitalize on this legal tool to usher in more viable and socially sound policies and measures to protect public space. To accomplish this, it is incumbent on governmental officials, judges, and individuals to join together to reexamine the nature of our fundamental rights and social responsibilities.

243. Neptune City v. Avon-by-the-Sea, 294 A.2d 47, 54 (N.J. 1972). See, e.g., Marks v. Whitney 491 P.2d 374, 380 (Cal. 1971) ("The public uses to which tidelands are subject are sufficiently flexible to encompass changing public needs. In administering the trust the state is not burdened with an outmoded classification favoring one mode of utilization over another."); In re Water Use Permit Applications, 9 P.3d 409, 447 (Haw. 2000) ("The public trust, by its very nature, does not remain fixed for all time, but must conform to changing needs and circumstances."); Orion Corp. v. State, 747 P.2d 1062, 1073 (Wash. 1987) (en banc) ("The trust's relationship to navigable waters and shorelands resulted not from a limitation, but rather from a recognition of where the public need lay."). 